\title{
Emerging molecular subtypes and therapeutic targets in B-cell precursor acute lymphoblastic leukemia
}

\author{
Jianfeng $\mathrm{Li}^{1}$, Yuting Dai ${ }^{1}$, Liang Wu ${ }^{1}$, Ming Zhang ${ }^{1}$, Wen Ouyang ${ }^{1}$, Jinyan Huang $(\varangle)^{1,2}$, Saijuan Chen $(\bowtie)^{1,2}$ \\ ${ }^{1}$ Shanghai Institute of Hematology, State Key Laboratory of Medical Genomics, National Research Center for Translational Medicine at \\ Shanghai, Ruijin Hospital Affiliated to Shanghai Jiao Tong University School of Medicine, Shanghai 200025, China; ${ }^{2}$ Pôle de Recherches \\ Sino-Français en Science du Vivant et Génomique, Laboratory of Molecular Pathology, Ruijin Hospital Affiliated to Shanghai Jiao Tong \\ University School of Medicine, Shanghai 200025, China
}

(C) The Author(s) 2020. This article is published with open access at link.springer.com and journal.hep.com.cn

\begin{abstract}
B-cell precursor acute lymphoblastic leukemia (BCP-ALL) is characterized by genetic alterations with high heterogeneity. Precise subtypes with distinct genomic and/or gene expression patterns have been recently revealed using high-throughput sequencing technology. Most of these profiles are associated with recurrent nonoverlapping rearrangements or hotspot point mutations that are analogous to the established subtypes, such as DUX4 rearrangements, MEF2D rearrangements, ZNF384/ZNF362 rearrangements, NUTM1 rearrangements, $B C L 2 / M Y C$ and/or BCL6 rearrangements, ETV6-RUNX1-like gene expression, PAX5alt (diverse $P A X 5$ alterations, including rearrangements, intragenic amplifications, or mutations), and hotspot mutations PAX5 (p.Pro80Arg) with biallelic PAX5 alterations, IKZF1 (p.Asn159Tyr), and ZEB2 (p.His1038Arg). These molecular subtypes could be classified by gene expression patterns with RNA-seq technology. Refined molecular classification greatly improved the treatment strategy. Multiagent therapy regimens, including target inhibitors (e.g., imatinib), immunomodulators, monoclonal antibodies, and chimeric antigen receptor T-cell (CAR-T) therapy, are transforming the clinical practice from chemotherapy drugs to personalized medicine in the field of risk-directed disease management. We provide an update on our knowledge of emerging molecular subtypes and therapeutic targets in BCP-ALL.
\end{abstract}

Keywords BCP-ALL; subtypes; translocation; aneuploidy; sequence mutations

\section{Introduction}

B-cell precursor acute lymphoblastic leukemia (BCPALL) is a blood cancer that originates from B-lymphoid progenitors $[1,2]$. Genetic susceptibility and somatic clonal expansion (tumor acquired) are the hallmarks and biological basis of BCP-ALL. The enrichment of chromosomal alterations, including genomic translocations and entire chromosome losses or gains (aneuploidy), DNA copy number variations (CNVs), and sequence mutations, are common in leukemic blast cells of BCP-ALLs [3-7]. In the past few years, numerous molecular subtypes with distinct genetic abnormalities and clinical significance have been identified in multicenter, global collaboration

Received August 7, 2019; accepted September 4, 2020

Correspondence: Jinyan Huang, huangjy@sjtu.edu.cn; Saijuan Chen, sjchen@stn.sh.cn cohort studies of patients with BCP-ALL [8-12]. A recognition of these multifaceted genetic alterations contributing to leukemogenesis is vital in ensuring a precise risk stratification of the disease, which can then lead to improvements to cure rates in both adults and children with BCP-ALL [5,12-26]. Before the 1980s, with the combined effectiveness of health-care systems and the absence of actionable risk stratification factors, the fiveyear overall survival rate was only approximately $50 \%$ in children patients with BCP-ALL [27-29]. In recent years, the released data from multiple large-cohort clinical trials indicate a five-year overall survival rate that is higher than $90 \%$ in children [29-42]. In addition, the rapid advancement in new drugs and agents, including target inhibitors, i.e., tyrosine kinase inhibitors (TKIs) and epigenetic inhibitors, immunomodulators, monoclonal antibodies, and chimeric antigen receptor T-cells (CAR-T), may further improve the prognosis of relapsed or refractory $(\mathrm{R} / \mathrm{R})$ BCP-ALL $[13,43]$. 


\section{Overview of well-established molecular subtypes in BCP-ALL}

The translocation $\mathrm{t}(9 ; 22)(\mathrm{q} 34 ; \mathrm{q} 11.2)$ resulting in $B C R$ $A B L 1$ (Philadelphia, $\mathrm{Ph}$ ) fusion accounted for $15 \%-25 \%$ of adults and $2 \%-5 \%$ of children with BCP-ALL $[8,9,44]$. $B C R-A B L 1$ fusion proteins are considered to be signaling regulators and can trigger kinase pathway activation [4548]. Targeted treatments with TKIs have significantly improved the prognosis of patients with $B C R-A B L 1$ $[8,9,13,49,50]$. KMT2A (MLL) rearrangements account for $3 \%-4 \%$ of children with BCP-ALL, particularly in infants $(<1$ year old), and in $4 \%-10 \%$ of adult patients, mainly $>30$ years old, with BCP-ALL $[8,9,18,24,51,52]$. Additionally, this rearrangement is typically associated with poor prognosis $[24,52,53]$. The translocations $t(4 ; 11)$ $(\mathrm{q} 21 ; \mathrm{q} 23), \mathrm{t}(11 ; 19)(\mathrm{q} 23 ; \mathrm{p} 13.3)$, and $\mathrm{t}(9 ; 11)(\mathrm{p} 21 ; \mathrm{q} 23)$ resulting in $K M T 2 A-A F F 1, K M T 2 A-M L L T 1$, and $K M T 2 A-M L L T 3$, respectively, account for more than $90 \%$ of $K M T 2 A$ fusions in BCP-ALL $[8,9]$. The translocation $\mathrm{t}(12 ; 21)(\mathrm{p} 13 ; \mathrm{q} 22)$ resulting in ETV6-RUNX1 (also known as TEL-AML1) comprises approximately $15 \%$ $25 \%$ of children with BCP-ALL $[8,9,17,18]$. However, adults $(<1 \%)$ and patients with ETV6-RUNX1 rarely have the same sensitivity to chemotherapy, and relapse and death events are less common $[5,8,9,17,54,55]$. In addition, ETV6-RUNX1 fusion is detectable in 5\% healthy newborns based on DNA-based genomic inverse PCR for exploration of ligated breakpoint screening, but most never transform to BCP-ALL [56]. Transcription factor 3 (TCF3) is frequently involved in two types of translocations, namely, $\mathrm{t}(1 ; 19)(\mathrm{q} 23 ; \mathrm{p} 13)$ and $\mathrm{t}(17 ; 19)(\mathrm{q} 22 ; \mathrm{p} 13)$, which result in $T C F 3-P B X 1$ and $T C F 3-H L F$ fusions, respectively. $T C F 3-P B X 1$ accounts for approximately $4 \%-7 \%$ of children patients and $2 \%-5 \%$ of adult patients with BCPALL and is associated with intermediate outcomes $[8,9,12,54]$. TCF3-HLF is a rare gene fusion $(<1 \%$ of ALL), and relapse and death events are common $[25,57]$. $H L F$ is also involved in translocation $\mathrm{t}(18 ; 19)(\mathrm{q} 21 ; \mathrm{p} 13)$, thereby resulting in TCF4-HLF. Both TCF3-HLF and TCF4-HLF fusions retain the bZIP_2 domain and accompany the overexpression of $H \overline{L F}[8,9,25]$. The complex intrachromosomal amplification of chromosome 21 (iAMP21), which was first reported in 2003, helped to define a distinct cytogenetic subgroup [58,59]. This amplification occurs in approximately $2 \%-3 \%$ of children with B-lineage ALL, especially in adolescence $[5,9,12]$. This condition was originally considered a rare, high-risk subtype of BCP-ALL, but current intensive therapy has greatly improved its outcome $[59,60]$. High hyperdiploidy with a gain of at least five chromosomes is another independent predictor (along with ETV6-RUNX1) of favorable outcomes and accounts for approximately $15 \%-25 \%$ of patients with childhood BCP-ALL. However, high hyperdiploidy is rare in adults $(<1 \%)[8,9]$.
Conversely, hypodiploid ( $<44$ chromosomes) is uncommon $(2 \%-3 \%)$ and associated with inferior outcomes compared with high hyperdiploidy BCP-ALL. In addition, hypodiploid ( $<44$ chromosomes) is heterogeneous with distinct genetic abnormalities and gene expression profiles consisting of near-haploid BCP-ALL (25-29 chromosomes), low hypodiploid (32-39 chromosomes), and high hypodiploid (40-43 chromosomes) (Table 1) [5,12,23].

The well-established molecular subtypes of BCP-ALL have been mostly integrated into the guidance of therapy options (e.g., dose and times of chemotherapy and types of targeted drugs) [13]. Their integration has significantly improved the long-term survival of both adult and children patients. However, subtypes with poor/intermediate prognosis, including $B C R-A B L 1, K M T 2 A$ fusions, TCF3$P B X 1, H L F$ fusions, and low hypodiploid, are needed in intensive chemotherapy [5]. $B C R-A B L 1$ and $K M T 2 A$ fusions not only occur in BCP-ALL but also in other types of acute or chronic leukemia, including acute myeloid leukemia (AML), mixed phenotype acute leukemia (MPAL), and chronic myeloid leukemia [61-63]. A potential supposition is that the fusion of genes may occur at different stages of hematopoietic stem cell development.

\section{Emerging molecular subtypes in BCP-ALL}

\section{$D U X 4, M E F 2 D$, and $Z N F 384$ gene fusions}

Three new subtypes of adult and childhood BCP-ALL have been described recently $[16,18,20-22,64]$. The subtypes are involved in the rearrangements of DNA binding factors, including double homeobox 4 gene (DUX4), myocyte enhancer factor 2D (MEF2D), and zinc finger protein 384 (ZNF384), which separately account for approximately $4 \%-7 \%, 2 \%-4 \%$, and $3 \%-5 \%$ of childhood BCP-ALL and 4\%-7\%, 2\%-7\%, and 3\%-8\% of adult BCP-ALL [8,9,15-18,20-22,26,65-67]. DUX4-r, ZNF384-r, and MEF2D-r BCP-ALL are associated with favorable, intermediate, and poor diagnoses, respectively. In most patients, $D U X 4$ overexpression is the consequence of $D U X 4$ fusion, typically $I G H$ but rarely $E R G[17,20,21]$. By contrast, the partner genes of $M E F 2 D$ and ZNF384 are complex and diverse. A total of 9 genes (BCL9, SS18, FOXJ2, CSF1R, DAZAP1, STAT6, HNRNPUL1, $H N R N P H 1$, and HNRNPM) and 11 genes (EP300, TCF3, TAF15, CREBBP, EWSR1, ARID1B, SMARCA2, SMARCA4, SYNRG, NIPBL, and CLTC) have been reported as fusion partners of MEF2D and ZNF384 [8,15-18,20,22,66-68], respectively. Translocations $\mathrm{t}(1 ; 1)(\mathrm{q} 21 ; \mathrm{q} 22)$ and $\mathrm{t}(1 ; 19)(\mathrm{q} 22 ; \mathrm{q} 13)$ resulting in $M E F 2 D-B C L 9$ and MEF2D-HNRNPUL1, respectively, are the top two items in $M E F 2 D-r$ BCP-ALL, accounting for $70 \%$ and $15 \%$ of the cases. EP300, TCF3, and TAF15 are the most common $5^{\prime}$ genes rearranged to ZNF384 with 
translocations $\mathrm{t}(12 ; 22)(\mathrm{p} 13 ; \mathrm{q} 13), \mathrm{t}(12 ; 19)(\mathrm{p} 13 ; \mathrm{p} 13)$, and $\mathrm{t}(12 ; 17)(\mathrm{p} 13 ; \mathrm{q} 11)$, representing approximately $50 \%, 10 \%$ $20 \%$, and $10 \%$ of ZNF384 fusion-positive cases.

$D U X 4$, located within a D4Z4 repeat array in the subtelomeric region of chromosome 4 , is a key transcription factor regulating embryonic development and is not expressed in normal B-cells. DUX4 can bind a large percentage of activated genes in early developing embryos and improve the accessibility of genes as early as the 2- to 4-cell stages [20,21,69,70]. Intragenic deletions of $E R G$ were previously reported in approximately $5 \%$ of children with BCP-ALLs, but they were designated as the biological feature in DUX4-r cases [5,21]. Functional studies show that DUX4 rearrangements, as an early initiating event in leukemogenesis, can bind to an intragenic region of $E R G$ and cause the overexpression of ERGalt with a noncanonical first exon and transcript. Aberrant ERGalt preserves the DNA binding and transactivating domains and encodes a truncated C-terminal $E R G$ protein. The transcriptional activity of wild-type $E R G$ is inhibited by the ERGalt protein-transforming leukemic blast cells $[5,20,21,71]$. Interestingly, despite the presence of approximately $40 \%-50 \%$ of genetic alterations in $I K Z F 1$ deletions related to poor outcomes in other subtypes with BCP-ALL [72], DUX4-r BCP-ALL can achieve excellent outcome $[5,12,17,18,21]$. Recent studies have reported that IGH-DUX4 translocation occurs on the silenced IGH allele, thereby reducing the oncogenic stress of DUX4's high-level expression. The ERG deletions have a positive impact on the prognosis ( $E R G$ deletion positive/ negative: five-year EFS $93 \% / 68 \%, P=0.022$; five-year OS $97 \% / 75 \%, P=0.029)[73,74]$.

$M E F 2 D$ is a transcription factor that can specifically bind to the myocyte-specific enhancer factor 2 (MEF2) element $5^{\prime}$-YTA[AT](4)TAR-3'. It belongs to the MEF2 gene family that contributes to the differentiation of muscle and neural cells, cardiac morphogenesis, formation of blood vessels, growth factor responsiveness, survival of neuronal cells, and acute leukemia [75,76]. As a member of the MEF2 gene family, $M E F 2 C$ is an activated oncogene in early T-cell precursor ALL, a subtype of high risk Tlineage ALL [12,77-82]. In 2005, MEF2D-DAZAP1 was reported in the TS-2 cell line, as established from a three-year-old girl with ALL; it was found to contain $\mathrm{t}(1 ; 19)(\mathrm{q} 23 ; \mathrm{p} 13.3)$ but was lacking the TCF3-PBX1 fusion [83]. In 2016, multiple research groups who used RNA-seq recognized simultaneously the $M E F 2 D$ fusion in a subgroup of patients with BCP-ALL $[16,18,20,64]$. These studies determined that $M E F 2 D$ fusions can retain the MADS box domain required to mediate DNA binding with enhanced $M E F 2 D$ transcriptional activity. The heterogeneous nuclear ribonucleoproteins, including HNRNPUL1, HNRNPH1, and HNRNPM, are involved in $M E F 2 D-r$ ALL $[8,9,15]$. These proteins can bind RNA and are associated with pre-mRNA processing in the nucleus. Histone deacetylase 9 (HDAC9), a target gene of $M E F 2 D$, is significantly upregulated in $M E F 2 D-r$ patients, providing an optional therapeutic strategy by using histone deacetylase inhibitors, such as panobinostat $[5,16,18]$. Staurosporine and venetoclax have recently been reported to be effective in inducing the caspase-dependent proteolysis of MEF2D-fusion proteins and apoptosis in MEF2Dfusion $^{+}$ALL cells [84].

ZNF384, also called $C I Z$ or $N M P 4$, can encode a C2H2type zinc finger protein, whose function remains largely elusive, although it may function as a transcription factor. ZNF384 fusions are often diagnosed as BCP-ALLs with an expression of cell surface markers of myeloid lineage (CD13 and $\mathrm{CD} 33$ ) or as $\mathrm{B} /$ myeloid $(\mathrm{B} / \mathrm{M})$ MPAL comprising approximately $50 \%$ of B/M MPAL [63]. In 2002, seven cases with ZNF384-r acute leukemia and recurrent EWSR1-ZNF384 and TAF15-ZNF384 were reported [85]. On the basis of large-cohort RNA-seq data analysis, ZNF384-positive patients with BCP-ALL were identified as a prognostic subtype with distinct gene expression features [8,9,16-18,20,22,65,66,86,87]. All ZNF384 fusions keep their entire coding region. Cell apoptotic response, MAPK signaling, and JAK-STAT signaling pathways are significantly upregulated in this subtype $[8,22]$. Cardiotrophin-like cytokine factor 1 $(C L C F 1)$ is one of the most upregulated genes in ZNF384-r BCP-ALL that can bind to CRLF1 to form a compound cytokine, thereby ultimately activating the JAK-STAT signaling pathway and B-cell proliferation in vivo $[22,88]$. In addition, up to $60 \%$ of patients with ZNF384 fusions also show alterations in their signaling molecules, such as NRAS and FLT3, and $40 \%$ have epigenetic mutations, particularly $S E T D 1 B, C R E B B P$, and EZH2.

\section{"Like" or "phenocopy" subtypes in BCP-ALL}

Somatic mutations in the coding region and gene expression profile can help us recognize "like" or "phenocopy" subtypes that share similar gene expression features but lack consistent biomarkers. In recent years, several multi-omics and large-cohort studies have identified such subtypes, including Ph-like, ETV6-RUNX1-like, $K M T 2 A$-like, and ZNF384-like [8,9]. Integrated datasets showed that Ph-like and ETV6-RUNXI-like account for approximately $6 \%-15 \%$ and $2 \%-3 \%$ of children patients and $20 \%-25 \%$ and $<1 \%$ of adult patients with BCPALL. However, both KMT2A-like and ZNF384-like are rare $(<1 \%)$. Ph-like and ETV6-RUNX1-like are associated with poor and intermediate outcomes. The prognoses of $K M T 2 A$-like and ZNF384-like remain unclear because of limitation of sample size $[8,9,12]$.

The Ph-like subtype is $B C R-A B L 1$ negative, but its gene expression feature is similar to that of $B C R-A B L 1$-positive patients [89-93]. The Ph-like subtype was registered in the 
2016 revision to the WHO classification of myeloid neoplasms and acute leukemia [19]. Rearrangements of $C R L F 2$ (e.g., IGH-CRLF2 and P2RY8-CRLF2 atapproximately 30\%-50\%), ABL1/ABL2 (10\%), JAK2 (10\%), the erythropoietin receptor gene (EPOR, 5\%-10\%), and PDGFRB (5\%) are the major chromosomal markers. Sequence mutations of signaling molecules, such as JAK-STAT signaling and Ras signaling (e.g., NRAS, $K R A S, J A K 2$, and PTPN11), account for up to $15 \%-20 \%$ of Ph-like cases [8,9]. BCR-ABL1 and Ph-like are associated with poor response to chemotherapy but are sensitive to TKIs, such as imatinib and dasatinib.

The ETV6-RUNX1-like subtype was defined as ETV6$R U N X 1$ fusion negative and coexists with other ETV6 and $I K Z F 1$ alterations [17], accounting for approximately 10\%-20\% of the ETV6-RUNX1/-like subtype. The ETV6-RUNX1-like subtype is also significantly enriched in children patients, and more than $80 \%$ of cases of ETV6$R U N X 1$-like subtype are children $[8,9]$.

The KMT2A-like and ZNF384-like are recently defined subtypes, accounting for $5 \%-15 \%$ and $7 \%-10 \%$ of the $K M T 2 A /$-like and ZNF384/-like [8,9]. Rare fusions, such as MED12-HOXA9 and AFF1-TMEM156, are found in KMT2A-like cases. Notably, HOXA9 is deregulated in $K M T 2 A$ fusion-positive patients, and $A F F 1$ is the most common partner gene in $K M T 2 A$ fusions [8,9]. Recurrent ZNF362 fusions (SMARCA2-ZNF362 and TAF15ZNF362) are found in ZNF384-like ALL. The fusion partner genes, including $S M A R C A 2$ and TAF15, and the sequence mutations of $Z E B 2, C R E B B P$, and $S E T D 1 B$, are found in both ZNF384- $r$ and ZNF362-r BCP-ALL. The zinc finger domains are retained in both fusion proteins [8].

The Ph-like subtype can successfully exemplify significant improvements in prognosis by seeking the phenocopied events. However, extra effort is required to identify other possible phenocopied subtypes (e.g., $H L F$ fusion-like and hypodiploid-like subtypes) [8]. Moreover, the natural history and cell-of-origin of these "like" or "phenocopy" subtypes are still largely elusive. These gaps may prevent researchers from understanding the potential prognostic factors. A comprehensive comparison of the subtypes sharing similar gene expression profiles in many other aspects, such as cancer cell population, inherited or de novo variants within a noncoding region, aberrant splicing, bacterial and viral infections, chromatin accessibility, and/or epigenetics alterations, may provide more hints $[27,87,94-105]$.

\section{PAX5-driven subtypes: PAX5alt and PAX5 p.Pro80Arg}

Paired box 5 (PAX5) is a member of the paired box (PAX) family and is an early B-lineage-specific transcriptional activator protein. Genetic alterations of PAX5, including DNA CNVs, sequence mutations, and chromosomal translocations, are common in patients with BCP-ALL
[106]. CNVs and non-silent sequence mutations of $P A X 5$ occur in about $30 \%$ and $5 \%-9 \%$ of all BCP-ALL patients $[8,9,18]$. Chromosomal translocations of PAX5, which result in fusion genes, account for approximately 5\%-7\% of children and $2 \%-4 \%$ of adults with BCP-ALL $[8,107]$. $P A X 5$ fusions are highly heterogeneous and complex. At least 24 partner genes (e.g., PAX5-JAK2, PAX5-ETV6, and $P A X 5-N O L 4 L)$ of $P A X 5$ fusions are involved in $P A X 5$ rearrangements, thereby resulting in the expression of chimeric in-frame fusion transcript [9]. Furthermore, 15\%$25 \%$ of patients with $P A X 5$ fusions have presented Ph-like subtype characteristics, mainly those of PAX5-JAK2 and $P A X 5$-ZCCHC7. Nearly $20 \%$ of $P A X 5$ fusions coexist with other chromosomal alterations, including $C R L F 2$ fusions, ETV6-RUNX1, TCF3-PBX1, KMT2A, BCR-ABL1, and iAMP21. For instance, $C R L F 2$ fusions coexist in up to $10 \%$ of all PAX5 fusions, such as PAX5-NOL4L, PAX5AUTS2, PAX5-NCOA5, and P2RY8-CRLF2 pairs. Notably, these fusions have shown different gene expression profiles compared with the $C R L F 2$ fusions clustered to the $B C R-A B L 1 / \mathrm{Ph}-$ like subtype and account for up to $20 \%$ of all $C R L F 2$ fusions $[8,9]$.

In recent studies, two new subtypes (PAX5-driven) with specific PAX5 alterations have been defined in BCP-ALL. The first subtype is PAX5alt with rearrangements, intragenic amplifications, or sequence mutations of PAX5 $[8,9]$. The second subtype is the hotspot mutation PAX5 p.Pro80Arg (P80R) and biallelic PAX5 alterations $[8,9,65,86]$. PAX5alt and PAX5 P80R occur in $7 \%-10 \%$ and $3 \%-4 \%$ of childhood and $4 \%-8 \%$ and $1 \%$ of adult patients with BCP-ALL. Moreover, both subtypes are associated with intermediate outcomes. Additionally, compared with adults with PAX5alt, adults with PAX5 P80R had more superior outcomes $[8,9]$.

Diverse $P A X 5$ alterations were found in approximately $75 \%$ of patients in the PAX5alt subtype. The alterations include PAX5 rearrangements (PAX5-ETV6, PAX5-NOL4L, PAX5-AUTS2, PAX5-CBFA2T3, PAX5-DACH1, PAX5$F O X P 1$, and $P A X 5-Z N F 521$ ), sequence mutations (PAX5 p.Pro32Ser (P32S), p.Pro34Leu (P34L), p.Arg38Cys (R38C)/p.Arg38His (R38H), and p.Arg140Leu (R140L)/ p.Arg140Gln (R140Q)), and CNVs (mainly one copy loss and focal intragenic amplification of PAX5). The ratio of CNVs that is positive for PAX5alt showed lesser frequency than that of other subtypes, but focal intragenic amplification (8/10) of PAX5 (PAX5amp) was observed [9]. Apart from $P A X 5$ alterations, other common genetic alterations in the PAX5alt subtype are the signaling molecules (e.g., $N R A S, K R A S$, and FLT3), cell-cycle regulator CDKN2A deletions, B-cell development (IKZF1 and VPREB1 deletions), transcriptional factors (ZFP36L2 and ETV6), and epigenetics modifier (KDM6A). The gene expression data showed that cytokine receptor genes (e.g., $P D G F R B$ and FLT3) are enriched in PAX5alt, which is in line with the activation mutations in signaling pathways $[8,9]$. 
Point mutations of PAX5 P80R in the DNA binding can affect the ability of PAX5 to bind DNAs and regulate expressions. These mutations represent the first molecular subtype defined on the basis of homogeneous hotspot mutations and gene expression profiles $[8,9,65,86,108,109]$. Most patients with PAX5 P80R presented distinct gene expression profiles and uniform genetic alterations. PAX5 P80R patients can promote the biallelic alteration of $P A X 5$ in vivo, and this alteration frequently coexists with the hemizygous loss of $P A X 5$. This scenario results in a higher mutation allele frequency compared with that of other PAX5 point mutations [9]. Hemizygous PAX5 P80R without the deletion of the wildtype $P A X 5$ allele may present gene expression features in other subtypes, such as the Ph-like and PAX5alt. Activating mutations in signaling (Ras and JAK/STAT pathways), including PTPN11 and $I L 7 R$, and inactivating mutations in epigenetic factor SETD2 are the most common genetic alterations coexisting with PAX5 P80R $[8,9,65,86]$.

PAX5-driven subtypes showed high heterogeneity in genetics, such as diverse patterning genes involved in $P A X 5$ fusions, and sequence mutations scattered on the coding region of $P A X 5$. This characteristic may further require diverse therapy agents, including a combination of chemotherapy and multi-inhibitors, and possibly immunotherapy. Additionally, different prognoses between adult and childhood PAX5alt indicates the presence of additional age-dependent factors that may affect the vitality, aggressiveness, and drug responsiveness of leukemic cells in this BCP-ALL subtype [9].

\section{NUTM1 gene fusion}

The NUT midline carcinoma family member 1 (NUTM1), also called nuclear protein in the testis, is located within chromosome 15q14. Previously, NUTM1 fusions were mainly reported as translocations $\mathrm{t}(15 ; 9)(\mathrm{q} 14 ; \mathrm{q} 34)$ and $\mathrm{t}(15 ; 19)(\mathrm{q} 14 ; \mathrm{p} 13)$ that could result in BRD3-NUTM1 and $B R D 4-N U T M 1$ [110-113]. In recent years, rearrangements of NUTM1 involving ACIN1 (14q11), CUX1 (7q22), AFF1 (4q21), BRD9 (5p15), ZNF618 (9q32), IKZF (7p12), and SLC12A6 (15q14) have been identified as a specific subtype $(1 \%-2 \%)$ in BCP-ALL. This subtype is preliminarily considered a subtype of BCP-ALL associated with a favorable prognosis $[8,9,16-18,114,115]$. The $H O X A$ gene family, particularly $H O X A 9$, is upregulated in the NUTM1-r ALL, which has not been described in NUT midline carcinoma [8]. KMT2A fusions can regulate leukemogenic gene expressions, particularly the HOXA gene family, by modulating the acetylation of H3K27 and disturbing the telomeric silencing 1-like histone 3 lysine 79 (H3K79) methyltransferase DOT1L [51,116]. HOXA9 can cooperate with the JAK/STAT signaling pathway and drive leukemia development [117]. The molecular mechanism of
NUTM1-r ALL is still largely unknown and thus needs further study. Both NUTM1 and KMT2A fusions may drive leukemogenesis by disturbing epigenetic status and upregulating the HOXA gene family.

\section{Other gene fusions and point mutations}

\section{Rearrangements of BCL2/MYC and/or BCL6}

Translocations $\mathrm{t}(14 ; 18)(\mathrm{q} 32 ; \mathrm{q} 21), \mathrm{t}(8 ; 14)(\mathrm{q} 24 ; \mathrm{q} 32)$, and $\mathrm{t}(3 ; 14)(\mathrm{q} 27 ; \mathrm{q} 32)$ that result in $B C L 2-I G H, M Y C-I G H$, and/or BCL6-IGH fusions occur in approximately $2 \%$ of adults (mostly $>30$ years old) with BCP-ALL and are less common in children. These translocations are associated with consistently poor responses in early treatment [9]. Low levels of circulating $\mathrm{t}(14 ; 18)$-positive cells can be found in approximately $50 \%-70 \%$ of healthy individuals but never develop into a disease [118-121]. Chromosomal alterations in $B C L 2, M Y C$, and/or BCL6 have been frequently reported in chronic lymphocytic leukemia and double- or triple-hit lymphoma, which are rare in ALL with a B-cell-precursor immunophenotype [16,121-133]. The promoter regions of $B C L 2, M Y C$, and BCL6 are usually affected by $I G H$ translocations, causing an overexpression of the rearranged allele compared with the germline allele. This characteristic can dramatically activate the proliferation of leukemogenic blast cells [123]. At present, patients with the abovementioned alterations cannot be well cured because of the development of chemotherapy resistance $[9,121]$. This limitation poses a great challenge to patient treatment. The inhibition of cyclin-dependent kinase 7 (CDK7) has been reported as an optional target for reducing the resistance of BCL-2 in B-cell lymphoma models [133]. The developed therapeutic agents in B-cell lymphoma may also be effective in BCPALL. Additional functional assays and clinical tests are urgently needed to improve the survival rate in the $B C L 2 /$ $M Y C$ and/or BCL6-r BCP-ALL.

\section{ZEB2 p.His1038Arg (H1038R) and IGH-CEBPE gene fusion}

Zinc finger E-box binding homeobox 2 (ZEB2), a member of the Zfh1 family of 2-handed zinc finger/homeodomain proteins, is a nuclear protein that can bind DNA and repress its transcriptional activity; this protein interacts with activated SMAD, a DNA binding protein, and recognizes an 8-bp palindromic sequence (GTCTAGAC) called the Smad binding element [134]. CCAAT enhancer binding protein epsilon (CEPBE) is a bZIP transcription factor that binds to certain DNA regulatory regions by means of homodimer formation. In a recent study, a hotspot mutation of ZEB2 p.His1038Arg (H1038R) and 
translocation $\mathrm{t}(14 ; 14)$ (q11;q32), which results in $I G H$ $C E B P E$ with a truncation of the $3^{\prime} \mathrm{UTR}$, is defined as a rare subtype $(<1 \%)$ sharing similar gene expression features. The rs $2239630 \mathrm{G}>\mathrm{A}$ at the promoter of $C E B P E$ is associated with the IGH-CEBPE translocated ALL with increased $C E B P E$ expression [135]. More than $50 \%$ of patients in this subtype also have $N R A S$ sequence mutations. The leukemic oncogene $L M O 1$ is significantly upregulated in this subtype and is an important component of a transcriptional complex that includes TAL1, TCF12/ HEB, TCF3/E2A, MYB, RUNX1, GATA3, and LDB1. This transcription complex can form a positive interconnected autoregulatory circuit that impacts the transformation in approximately $60 \%$ of patients with T-cell ALL (TALL) $[77,136]$. In addition, SMAD1 and $B M P 2$ are significantly downregulated in this subtype; these genes can regulate the signals of the bone morphogenetic proteins and are involved in a range of biological activities, including morphogenesis, cell growth, apoptosis, development, and immune responses [137-140]. Preliminarily, ZEB2 mutation is associated with poor event-free survival and high relapse in patients with BCP-ALL [141]. The clinical implications of ZEB2 p.His1038Arg (H1038R) and $I G H-C E B P E$ gene fusion subtype are still largely unclear. Much larger sample sizes and functional tests are needed for this BCP-ALL subtype.

\section{IKZF1 p.Asn159Tyr (N159Y)}

$I K Z F 1$, also known as IKAROS, is a critical transcription factor related to the differentiation and maturation of the Bcell precursor. Somatic alterations of IKZFI are a hallmark of high-risk BCP-ALL with poor response to therapy $[72,109,142]$. Point mutations of IKZF1 p.Asn159Tyr
(N159Y) were recently recognized as a rare subtype $(<1 \%)$ in BCP-ALL. In light of the limitation of sample size, the outcomes of IKZF1 N159Y are still undermined. IKZF1 N159Y, which is located in the DNA binding domain, may impact its capability for DNA binding and gene transcription regulation. Sequence mutations of $K R A S$ are recurrent in patients with IKZF1 N159Y but lack extra copy number alterations. The gene expression data showed that the transcriptional coactivator YAP1 is significantly upregulated, which can drive $K R A S$-induced transformation through rescued cell viability in $K R A S$ dependent cells [143]. The chromatin remodeling SALL1 and the signaling factor $A R H G E F 28$ are also significantly upregulated in IKZF1 N159Y-positive patients. Meanwhile, the B-cell receptor signaling and JAK-STAT signaling pathways (e.g., FLT3, FLT4, and STAT5) are down-regulated in patients with IKZF1 N159Y. These two pathways are commonly activated in other BCP-ALLs $[8,9,144-146]$. At present, the public data show that IKZF1 N159Y-positive cases are still below 10. One case of IKZF1 N159T was reported in the chronic myelomonocytic leukemia cohort [147]. Surprisingly, de novo germline mutations, including IKZF1 N159S $(n=6)$ and IKZF1 N159T $(n=1)$, could exist at the same IKZF1 amino acid N159, which then would cause T-, B-, and myeloid cell-combined immunodeficiency, and a patient would develop T-ALL [148]. Pneumocystis jirovecii pneumonia is positive in all of patients with N159S or N159T mutations. A patient died at 2 years old without leukemia phenotype although the child received hematopoietic stem cell transplants [148]. Multi-center collaboration may accelerate the collection of patient data in this subtype for the further evaluation of its clinical significance (Table 1; Fig. 1A and 1B).

Table 1 Overview of biological subtypes of adult and childhood BCP-ALL

\begin{tabular}{|c|c|c|c|c|c|}
\hline Subtype & Adult & Childhood & Key features & Molecular targeting agents & Outcomes \\
\hline$\overline{\mathrm{Ph}}$ & $15 \%-25 \%$ & $2 \%-5 \%$ & $\begin{array}{l}\text { Gene fusion of } B C R-A B L 1(\mathrm{Ph}), \\
\text { mutation of } R U N X 1 \text {, and common } \\
\text { deletions of } P A X 5, I K Z F 1 \text {, and } \\
C D K N 2 A / 2 B\end{array}$ & $\begin{array}{l}\text { TKI; JAK/STAT, BTK/BCR, PD-1/ } \\
\text { PD-L1, CDK8, Aurora kinase A/B/C } \\
\text { inhibitors }\end{array}$ & $\begin{array}{l}\text { Poor outcome and } \\
\text { improved with } \\
\text { TKI }\end{array}$ \\
\hline Ph-like & $20 \%-25 \%$ & $6 \%-15 \%$ & $\begin{array}{l}\text { Gene fusions of } C R L F 2, A B L 1 / A B L 2, \\
J A K 2, E P O R \text {, PDGFRB, and } C S F 1 R \\
\text { and mutations of } N R A S, K R A S, J A K 2 \text {, } \\
\text { and PTPN11 }\end{array}$ & TKI; JAK/STAT, BCL2 inhibitors & $\begin{array}{l}\text { Poor outcome and } \\
\text { amenable to TKI } \\
\text { therapy }\end{array}$ \\
\hline KMT2A & $4 \%-10 \%$ & $3 \%-4 \%$ & $\begin{array}{l}\text { Gene fusions of } K M T 2 A \text { fused to } \\
A F F 1, M L L T 1, M L L T 3, M L L T 10, \\
\text { and } E P S 15 \text { and mutations of } N R A S, \\
K R A S, \text { and } F L T 3 ; \text { de-regulated gene } \\
\text { expression of } H O X A \text { gene family, } \\
\text { particularly HOAX9 }\end{array}$ & $\begin{array}{l}\text { DOT1L, HDAC, CDK4/6, BCL2, } \\
\text { MEN1 inhibitors }\end{array}$ & Poor outcome \\
\hline$K M T 2 A$-like & $<1 \%$ & $<1 \%$ & $\begin{array}{l}\text { Gene fusions of } M E D 12-H O X A 9 \text { and } \\
A F F 1-T M E M 156\end{array}$ & l & Poor outcome \\
\hline ETV6-RUNX1 & $<1 \%$ & $15 \%-25 \%$ & $\begin{array}{l}\text { Gene fusion of } E T V-R U N X 1 \text { and } \\
\text { mutations of } W H S C 1, K R A S \text {, and } \\
\text { NRAS }\end{array}$ & / & Favorable outcome \\
\hline
\end{tabular}


(Continued)

\begin{tabular}{|c|c|c|c|c|c|}
\hline Subtype & Adult & Childhood & Key features & Molecular targeting agents & Outcomes \\
\hline$\overline{E T V 6-R U N X 1-\text { like }}$ & $<1 \%$ & $2 \%-3 \%$ & $\begin{array}{l}\text { Co-existing ETV6 and IKZFI } \\
\text { aberrations; CD27 positive, } \\
\text { CD44 low to negative }\end{array}$ & / & $\begin{array}{l}\text { Intermediate } \\
\text { outcome }\end{array}$ \\
\hline$T C F 3-P B X 1$ & $2 \%-5 \%$ & $4 \%-7 \%$ & $\begin{array}{l}\text { Gene fusion of } T C F 3-P B X 1 \text { and } \\
\text { mutations of } T P 53\end{array}$ & CDK4/6 inhibitors & $\begin{array}{l}\text { Intermediate } \\
\text { outcome with } \\
\text { intensive therapy, } \\
\text { and association } \\
\text { with CNS relapse }\end{array}$ \\
\hline$H L F$ & $<1 \%$ & $<1 \%$ & $\begin{array}{l}\text { Gene fusions of } T C F 3-H L F \text { and } \\
T C F 4-H L F\end{array}$ & $\begin{array}{l}\text { CDK4/6, TKI, BCL2, BCR/BCL6 } \\
\text { inhibitors }\end{array}$ & Poor outcome \\
\hline$D U X 4$ & $4 \%-7 \%$ & $4 \%-7 \%$ & $\begin{array}{l}\text { Gene fusions of } I G H-D U X 4 \text { and } \\
E R G-D U X 4 \text {; de-regulated gene } \\
\text { expression of ERGalt; CD2 and } \\
\text { CD371 positive }\end{array}$ & / & $\begin{array}{l}\text { Favorable outcome } \\
\text { with } E R G \\
\text { deletions; } \\
\text { intermediate } \\
\text { outcome } \\
\text { without } E R G \\
\text { deletions }\end{array}$ \\
\hline$M E F 2 D$ & $2 \%-7 \%$ & $2 \%-4 \%$ & 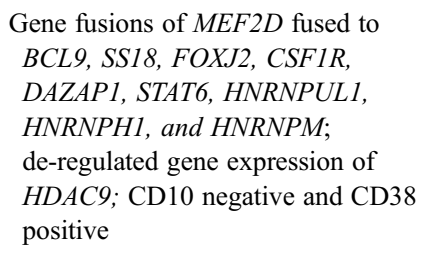 & HDAC inhibitors & Poor outcome \\
\hline ZNF384 & $3 \%-8 \%$ & $3 \%-5 \%$ & $\begin{array}{l}\text { Gene fusions of ZNF384 fused to } \\
E P 300, T C F 3, T A F 15, C R E B B P, \\
E W S R 1, A R I D 1 B, S M A R C A 2, \\
S M A R C A 4, S Y N R G, \text { and NIPBL } \\
\text { and mutations of NRAS, KRAS, } \\
F L T 3, P T P N 11, S E T D 1 B, Z E B 2, \\
\text { EZH2, KMT2D, and CREBBP; } \\
\text { mixed-phenotype }\end{array}$ & FLT3 inhibitors & $\begin{array}{l}\text { Intermediate } \\
\text { outcome }\end{array}$ \\
\hline ZNF384-like & $<1 \%$ & $<1 \%$ & $\begin{array}{l}\text { Gene fusions of ZNF362 fused } \\
\text { to SMARCA2 and TAF15 }\end{array}$ & / & l \\
\hline PAX5alt & $4 \%-8 \%$ & $8 \%-10 \%$ & $\begin{array}{l}\text { Gene fusions of } P A X 5 \text { fused to } \\
E T V 6, N O L 4 L, F O X P 1, A U T S 2, \\
C B F A 2 T 2 / 3, P 2 R Y 8-C R L F 2, \\
\text { deletions of } P A X 5, \\
\text { and mutations of } P A X 5, N R A S, \\
\text { KRAS, FLT3, and JAK1 }\end{array}$ & TKI & $\begin{array}{l}\text { Intermediate } \\
\text { outcome }\end{array}$ \\
\hline$B C L / M Y C$ & $1 \%-2 \%$ & $<1 \%$ & $\begin{array}{l}\text { Gene fusions of } I G H-B C L 2, \\
I G H-M Y C \text {, and } I G H-B C L 6\end{array}$ & CDK7 inhibitors; BCL2 inhibitors & Poor outcome \\
\hline NUTM1 & $<1 \%$ & $1 \%-2 \%$ & $\begin{array}{l}\text { Gene fusions of } N U T M 1 \text { fused to } \\
A C I N 1, C U X 1, A F F 1, B R D 9, \\
Z N F 618, S L C 12 A 6 \text {, and } I K Z F 1\end{array}$ & Bromodomain inhibitors & Favorable outcome \\
\hline High hyperdiploidy & $<1 \%$ & $15 \%-25 \%$ & $\begin{array}{l}>50 \text { chromosomes, mutations of } \\
\text { NRAS, KRAS, FLT3, PTPN1, } \\
K M T 2 D, \text { and } C R E B B P\end{array}$ & l & Favorable outcome \\
\hline Near-haploid & $<1 \%$ & $2 \%-3 \%$ & $\begin{array}{l}\text { 25-29 chromosomes, mutations of } \\
N R A S, F L T 3 \text {, and } P A X 5 \text {, and } \\
\text { inactivation of } I K Z F 3 \text { and } P A G 1\end{array}$ & BCL2 inhibitors & Poor outcome \\
\hline Low hypodiploid & $1 \%-2 \%$ & $10 \%-15 \%$ & $\begin{array}{l}\text { 32-39 chromosomes, mutations of } \\
T P 53 \text {, deletions of } C D K N 2 A / 2 B \\
\text { and } R B 2 \text {, and inactivation of } I K Z F 2\end{array}$ & BCL2 inhibitors & Poor outcome \\
\hline High hypodiploid & $<1 \%$ & $<1 \%$ & $40-43$ chromosomes & / & Poor outcome \\
\hline iAMP21 & $<1 \%$ & $2 \%-3 \%$ & $\begin{array}{l}\text { Complex structural alterations of } \\
\text { chromosome } 21\end{array}$ & l & $\begin{array}{l}\text { Intermediate } \\
\text { outcome }\end{array}$ \\
\hline
\end{tabular}




\begin{tabular}{|c|c|c|c|c|c|}
\hline & & & & & (Continued) \\
\hline Subtype & Adult & Childhood & Key features & Molecular targeting agents & Outcomes \\
\hline $\begin{array}{l}\text { PAX5 P80R } \\
\text { PA }\end{array}$ & $3 \%-4 \%$ & $<1 \%$ & $\begin{array}{l}\text { Hotspot mutations of } P A X 5 \\
\text { p.Pro80Arg (P80R) and activating- } \\
\text { mutations of NRAS, KRAS, FLT3, } \\
\text { and PTPN11 }\end{array}$ & TKI & $\begin{array}{l}\text { Intermediate } \\
\text { outcome }\end{array}$ \\
\hline IKZF1 N159Y & $<1 \%$ & $<1 \%$ & $\begin{array}{l}\text { Hotspot mutations of } I K Z F 1 \\
\text { p.Asn159Tyr (N159Y) }\end{array}$ & I & / \\
\hline $\begin{array}{c}\text { ZEB2 H1038R/ } \\
I G H-C E B P E\end{array}$ & $<1 \%$ & $<1 \%$ & $\begin{array}{l}\text { Gene fusion of } I G H-C E B P E \text { and } \\
\text { mutations of } Z E B 2 \text { p.His } 1038 \mathrm{Arg} \\
\text { (H1038R), NRAS, KMT2D, KRAS, } \\
K M T 2 A \text {, and } C D K N 2 A\end{array}$ & l & I \\
\hline
\end{tabular}

Percentages may not add up to $100 \%$ because of rounding. NA, not available.

Abbreviations: TKI, tyrosine kinase inhibitor.

\section{Diagnosis and molecular classification of BCP-ALL based on RNA-seq}

Genetic variations with clinical significance in BCP-ALL are structurally heterogeneous [18]. Multiple highthroughput sequencing approaches are highly recommended, as they can be utilized to accurately recognize the prognostic factors (e.g., fusion genes, gene expressiondependent subtypes, small sequence variants, and genomic duplications and deletions) and determine the strategic therapy [149]. RNA-seq is a single and comprehensive platform for BCP-ALL diagnosis and genomic classification in the laboratory and clinical settings $[9,43,150-152]$. For example, most of the known fusion genes (e.g., $B C R$ $A B L 1, E T V 6-R U N X 1$, and TCF3-PBX1) and new fusion genes (e.g., TCF3/4-HLF, NUTM1, DUX4, ZNF384/ $Z N F 362$, and $M E F 2 D$ fusions) in BCP-ALL can be detected by RNA-seq $[149,153]$. These newly identified recurrent DUX4, ZNF384, MEF2D, and NUTM1 fusions have distinct clinical features $[8,9,15,16,18,22,64]$. Notably, RNA-seq is also a reliable technology for simultaneously identifying the positive-fusion gene and the gene expression-dependent subtypes, including Ph-like, ETV6RUNX1-like, ZNF384-like, and KMT2A-like. Small sequence variants and genomic deletions (e.g., IKZF1) are also detectable by RNA-seq in BCP-ALL $[8,9,77,149,151-154]$. For instance, by re-analyzing the RNA-seq data from different BCP-ALL cohorts, the molecular subtypes characterized by hotspot mutations (e.g., PAX5 P80R and ZEB2 H1038R) could be identified [8]. Exon-level genomic deletions can cause differential transcripts expression (e.g., IKZFI exons 4-7, 2-7, 2-8, and 4-8) and thus can be used to predict genomic deletion events [153]. RNA-seq was also applied in AML diagnosis to accurately detect small sequence variants, FLT3-internal tandem duplication (ITD), and KMT2A-partial tandem duplication (PTD) events [155-157].

However, RNA-seq is more susceptible to bias factors originating from the samples, technology platform, and bioinformatics methodology (e.g., batch effect) compared with the DNA-based methods. Additional systematic benchmarks and further refinement of the methodology as a means of reducing the bias are needed to improve the stability and reducibility of the RNA-based methods $[149,158,159]$.

\section{New therapeutic targets and agents in BCP-ALL}

Intensive chemotherapy and allogeneic hematopoietic cell transplantation were the core options of BCP-ALL treatment in the past [27]. Treatment toxicity with relapsed events induced by chemotherapy drugs has been one of the most critical concerns awaiting further resolution in BCPALL $[13,27]$. The advent of emerging inhibitors/antagonists and immunotherapeutic has launched a new era of target therapy in several molecular subtypes or unselected BCP-ALL patients (Table 2). This ongoing transformation may continuously reduce the use of chemotherapy drugs and consequently achieve less treatment-induced resistance events [160]. Molecular target therapy and cellular immunotherapy in BCP-ALL are mainly dependent on the specific genetics and gene expression markers of the patients' leukemic cells in various molecular subtypes (e.g., $B C R-A B L 1, \mathrm{Ph}$-like, and $K M T 2 A$ fusions) or the shared or unselected cell surface marker (e.g., CD19 and CD22) (Fig. 2). Several molecular subtypes in BCP-ALL, including $\mathrm{R} / \mathrm{R}$ subtypes, have benefited from the new therapeutic targets and agents, although a large number of biomarkers are still rarely used as therapy targets.

$B C R-A B L 1$ and Ph-like (e.g., $B C R-A B L 1$-negative with fusions or mutations involved in $A B L 1 / A B L 2, P D G F R A / B$, $E P O R$, and $C S F 1 R$ ) have benefited from TKIs, including imatinib and/or dasatinib [91]. The combination of dasatinib and c-JUN N-terminal kinase (JNK) inhibitor, i.e., JNK-IN-8, can significantly improve the survival of the $B C R$-ABL1-positive mice model [161]. The cyclindependent kinases 8 (CDK8) inhibitor, YKL-06-101, 
A

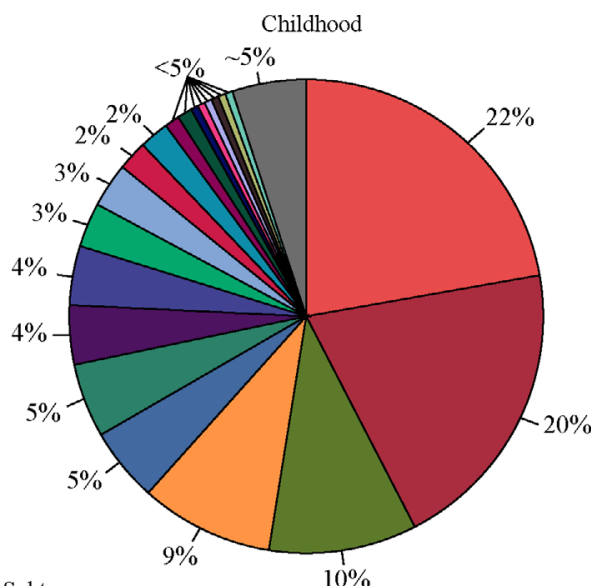

Subtypes

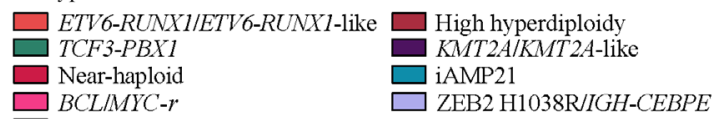

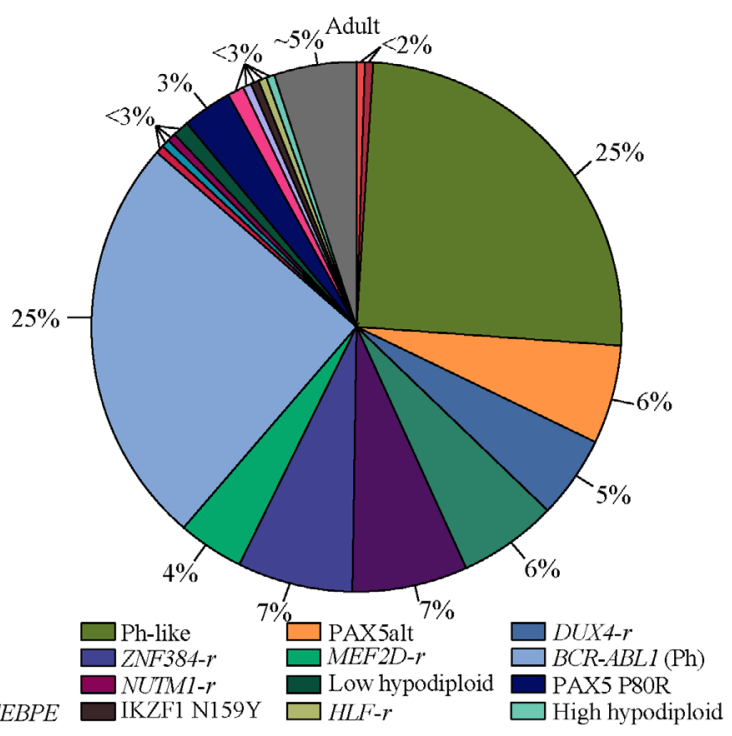

$\mathrm{B}$ $\square$ Others

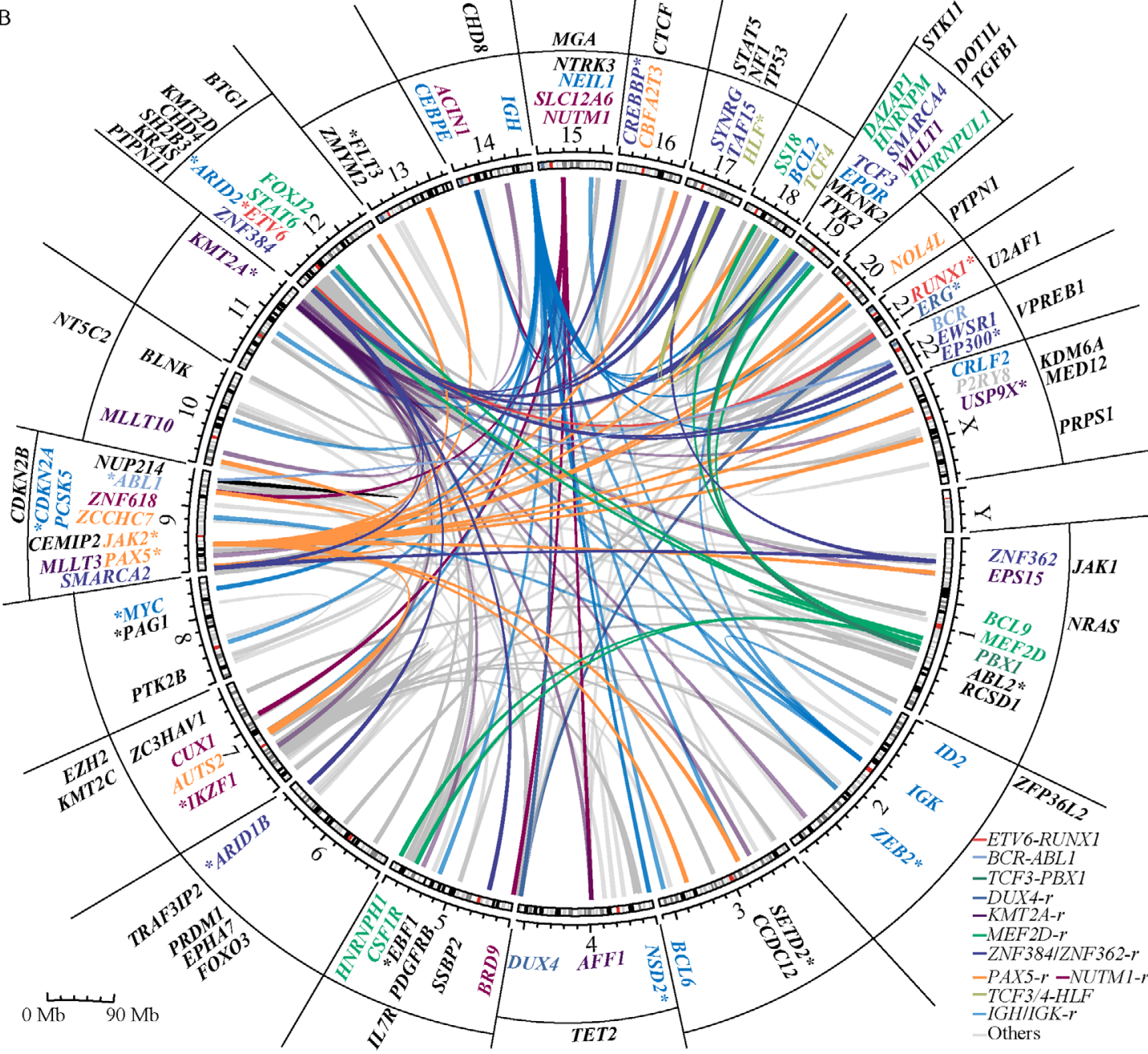

Fig. 1 Estimated percentage of major molecular subtypes and the genomic landscape of genetic mutations. (A) Pie plot represents the percentage of molecular subtypes in adult and children patients with BCP-ALL. (B) Cycle plot indicates the genomic landscape of major genetic alterations, including gene fusions, sequence mutations, and DNA CNVs. Chromosomes are separately arranged from chromosome 1 to $\mathrm{X}$. Gene fusions are linked by ribbons, and the fusions involving ETV6-RUNX1, BCR-ABL1, TCF3-PBX1, TCF3/4$H L F, I G H, K M T 2 A, M E F 2 D, Z N F 384, N U T M 1$, and PAX5 are highlighted. Genes affected by sequence mutations and DNA CNVs are listed at the external lines according to chromosome location. * Genes affected by different types of variations, i.e., fusion genes, CNVs, and sequence mutations. 


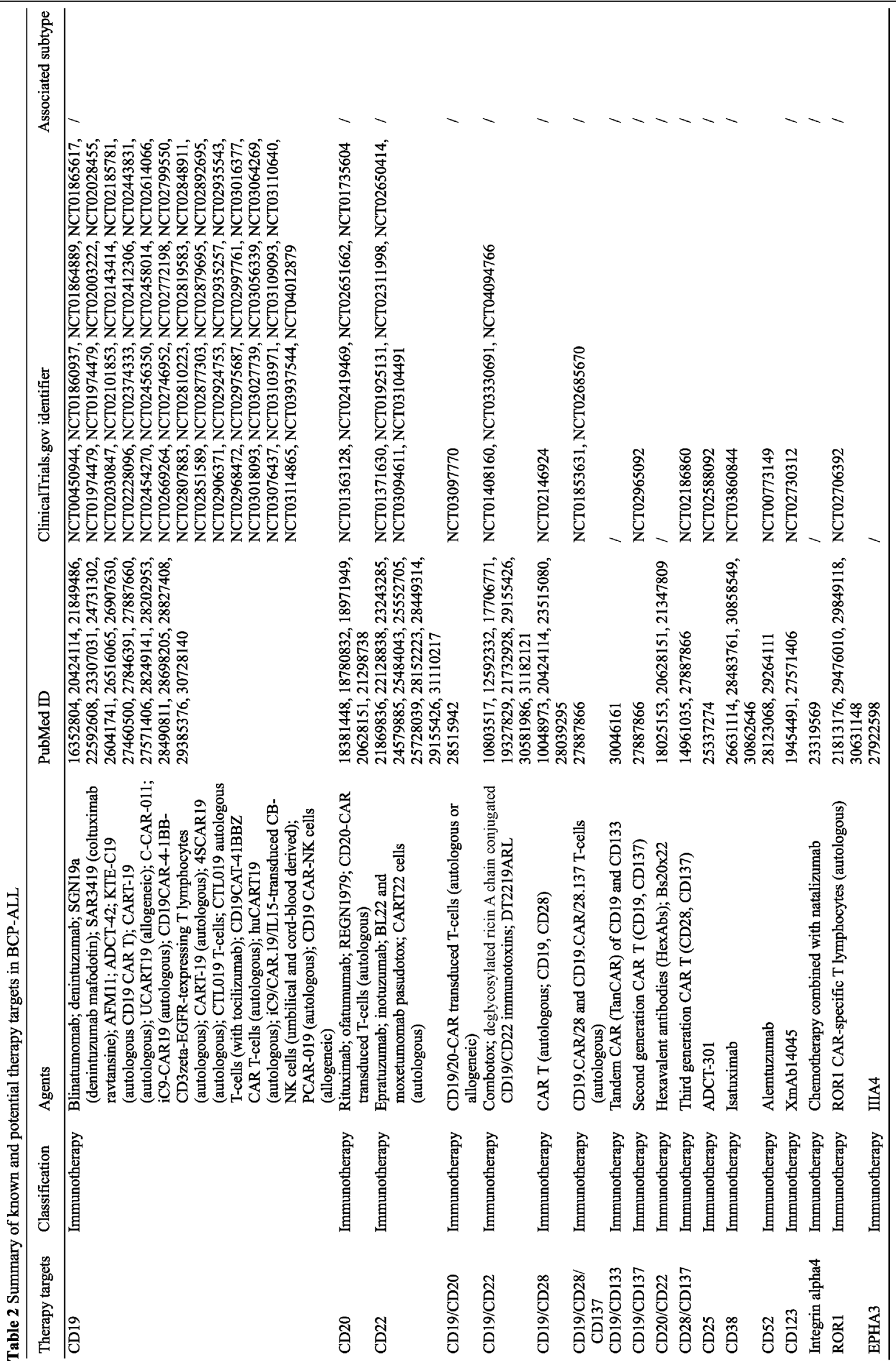




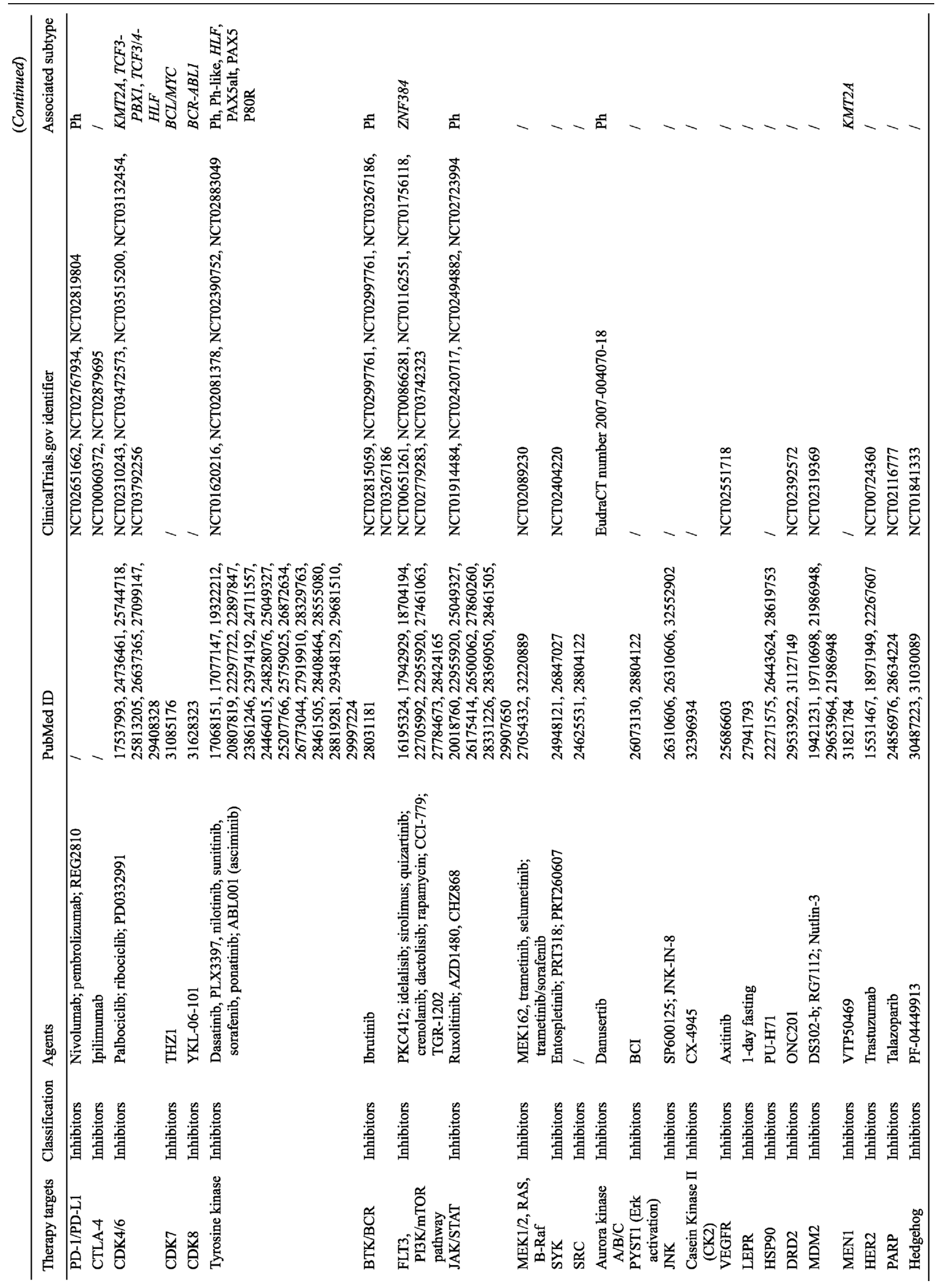




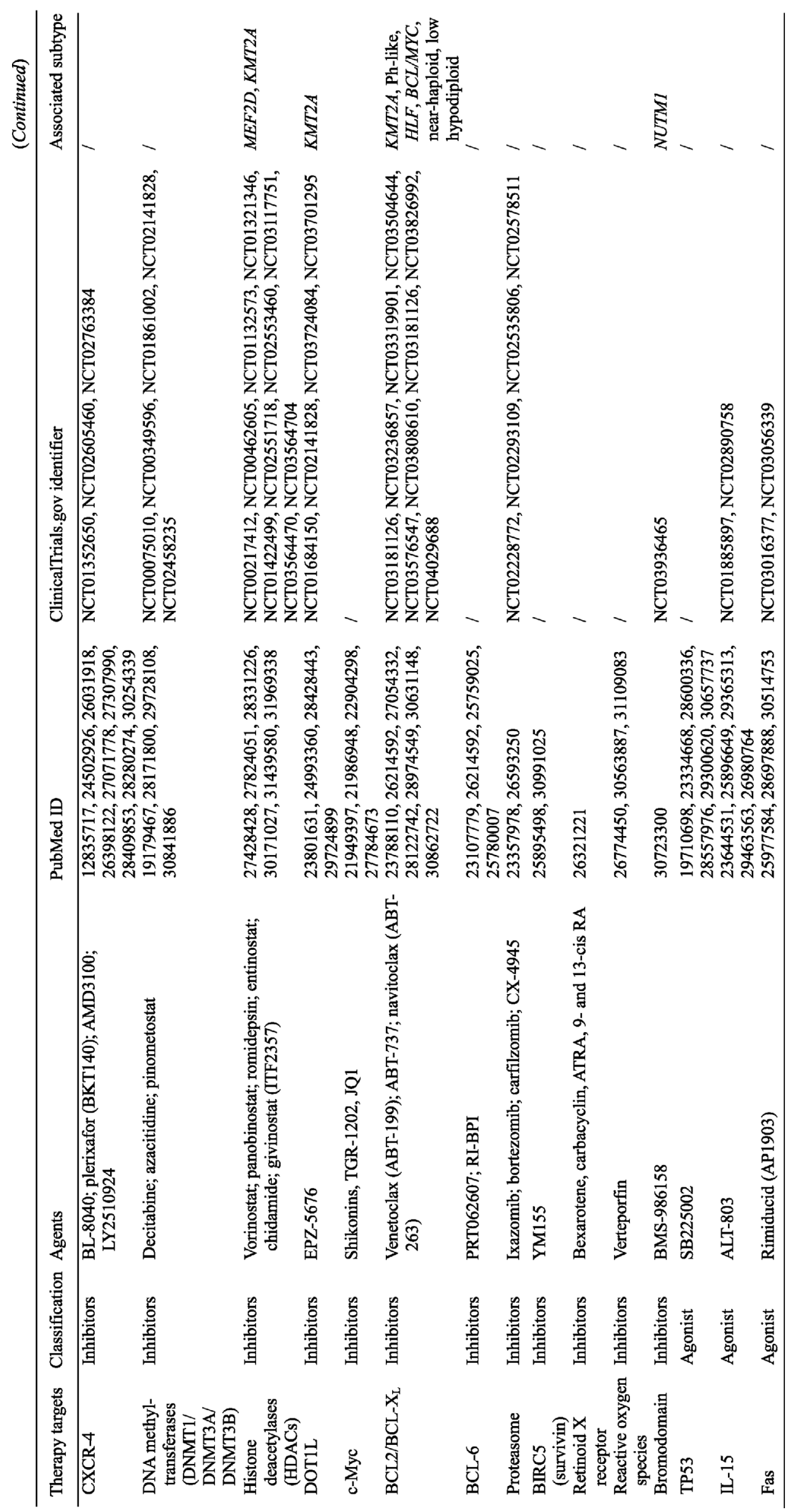




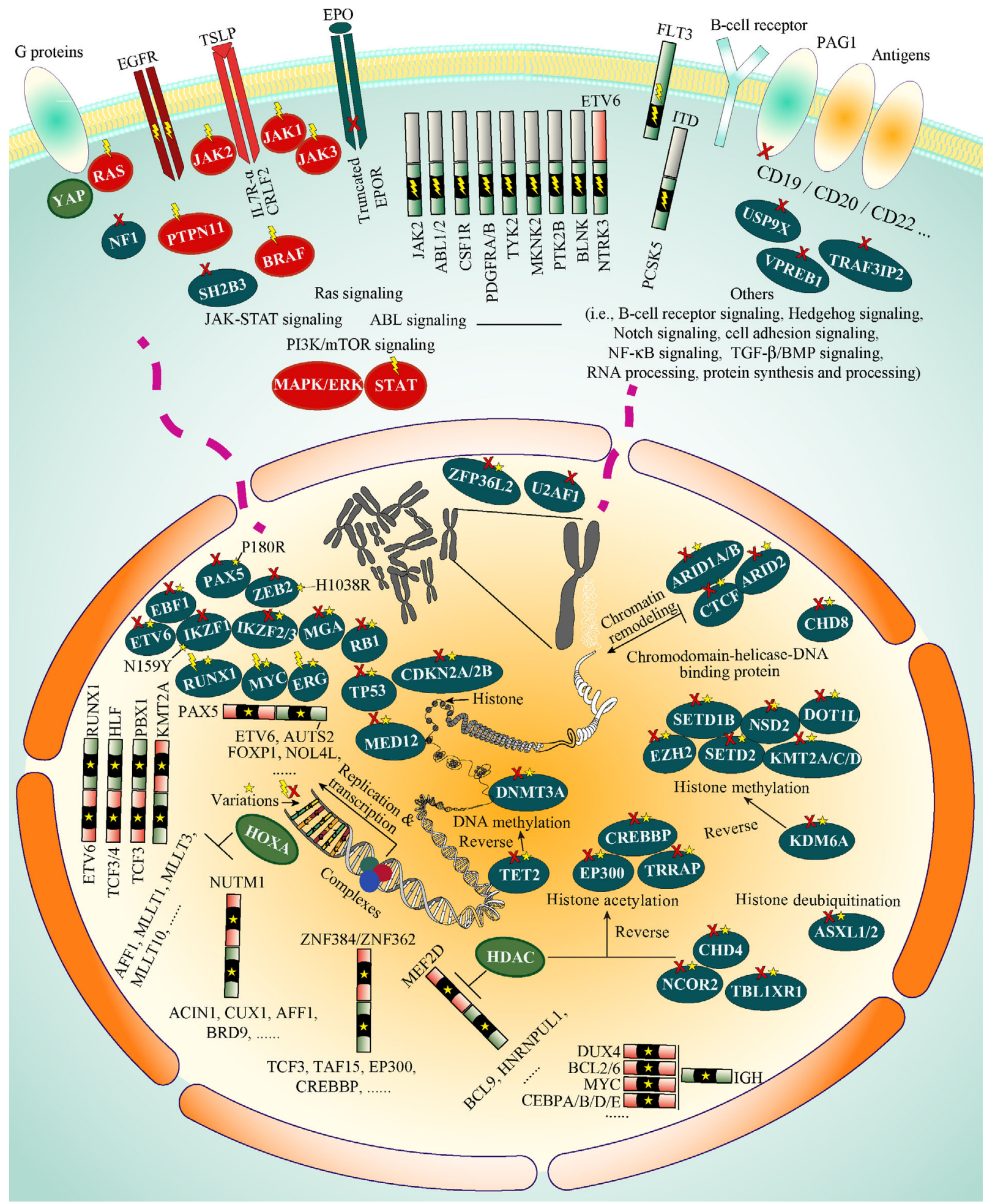

Fig. 2 Schematic of the candidate therapy pathways and targets from the cell surface to the nucleus of leukemic blast cells of patients with BCP-ALL. Signaling pathways (e.g., Ras signaling and JAK-STAT signaling) are mutant or/and activated in most subtypes of BCPALL. Other cytokine receptors and signaling pathways (e.g., Hedgehog signaling and Notch signaling in NUTM1 fusions; CRLF2, IL-7, and EPOR in Ph-like subtype; and PAG1 in near-haploid) are enriched in specific subtypes. Cell surface antigens, including CD19, CD20, and CD22, are the most promising CAR-T therapy targets. De-regulated tumor suppressors or cell cycle regulators (e.g., TP53 and $C D K N 2 A / 2 B$ ), transcription factors (e.g., $P A X 5, I K Z F 1$, and $E R G$ ), epigenetic modification (DNA methylation, histone acetylation, methylation, and deubiquitylation), and chromatin remodeling (e.g., $C T C F$ and $A R I D 1 A / B$ ) are the hallmarks of BCP-ALL in the nucleus. 
combined with the mTOR inhibitor can induce cell death of human $B C R-A B L 1$ leukemic cells [162]. Besides, both CDK4/6 inhibitors and Bcl-2 inhibitor are two types of molecular inhibitors that have been tested in R/R BCPALL [13,163], such as CDK4/6 inhibitors palbociclib (NCT02310243, NCT03472573, NCT03515200, NCT03132454, and NCT03792256) and Bcl-2 inhibitor venetoclax (NCT03826992, NCT03319901, NCT03181126, NCT04029688, NCT03808610, and NCT03504644). KMT2A fusions, $H L F$ fusions, and other R/R BCP-ALL may benefit from the inhibition of the cell cycle and apoptosis pathways. De-regulated DNA methylation or histone deacetylation has been found in several BCP-ALL subtypes (e.g., KMT2A and MEF2D fusions). DOT1L inhibitors (e.g., pinometostat/EPZ-5676) have been tested in phase I trials (NCT01684150 and NCT02141828) for KMT2A-r leukemia [164], and the phase 1b/2 trials (NCT03724084 and NCT03701295) are currently recruiting patients. HDAC inhibitors (e.g., vorinostat and panobinostat) have also been proposed to be benefiting several BCP-ALL subtypes (NCT02553460), including MEF2D fusions and $\mathrm{R} / \mathrm{R}$ BCP-ALL $[16,18,64,165]$. A newly proposed bioavailable Menin (MEN1)-KMT2A interaction inhibitor, VTP50469, showed that it can improve survival in patient-derived tumor xenograft mouse models of KMT2A-r BCP-ALL by suppressing a subset of $K M T 2 A$ fusion target genes [166]. Other activated critical cellular pathways regulating cell proliferation and apoptosis (i.e., pre-B/B-cell receptor, RAS, JAK-STAT, and mTOR/PI3K) [13] are also promising targeted pathways. Numerous clinical trials have been registered. The test combining multiple molecular compounds or agents are still in progress. Nonetheless, additional work is required to verify whether the intensive dose of chemotherapy drugs can be reduced reasonably.

Apart from the inhibitors/antagonists, immunotherapeutic agents, such as CAR-T and monoclonal antibodies, are another promising strategy for targeting specific cell surface markers overexpressed in leukemic cells. Immunotherapeutic agents can be used in the therapy of most children and adults with R/R BCP-ALL. The cell membrane antigens CD19, CD20, and CD22 are the three most promising targets of immunotherapeutic agents for BCP-ALL [167-174]. Other bispecific agents (e.g., Combobox for CD19/CD22) are becoming the nextgeneration CAR-T treatment options. As one of the hottest fields in BCP-ALL, a series of clinical trials of CAR-T for $\mathrm{R} / \mathrm{R}$ BCP-ALL is ongoing (e.g., NCT03330691, NCT03937544, NCT00450944, NCT04012879, and NCT04094766). The immunotherapeutic agents inotuzumab and blinatumomab were approved by the United States Food and Drug Authority for the therapy of adults with $\mathrm{R} / \mathrm{R}$ BCP-ALL, which can help to improve in the future the overall survival of both children and adults with BCP-ALL. In addition, the combination of the TKIs imatinib or dasatinib with multiagent chemotherapy is currently used in multiple clinical trials of R/R BCP-ALL. This treatment has markedly improved the outcome in BCP-ALL subset, as the five-year overall survival of patients has increased to $75 \%$ from less than $50 \%[12,175]$. Controlling early death, reducing therapy-induced resistance mutations, and comprehensive clinical management of adult patients are the potential key issues of medical precision in BCP-ALL treatment (Table 2) $[5,8,9,12,13,25,40,60,61,160,167,169,176-182]$.

\section{Conclusions}

Through decades of collaboration, more than $95 \%$ of patients with BCP-ALL have been classified and labeled using detectable genetic alterations, including distinct translocations of chromosomes, aneuploidy, DNA copy number alterations, sequence mutations, and gene expression patterns $[8-12,183]$. Refined risk stratification and the approval of new drugs and agents, including target inhibitors, monoclonal antibodies, and immunomodulators, and CAR-T, have resulted in an excellent five-year event-free survival and a five-year overall survival in children with BCP-ALL. However, the development of resistance and early death during treatments continue to pose daunting challenges for some subtypes of BCP-ALL, including hypodiploid ( $<44$ chromosomes), $H L F-$ arranged, $B C L 2 / M Y C-r, B C R-A B L 1 / \mathrm{Ph}-$ like, KMT2A-r, and $M E F 2 D-r$ BCP-ALL. Additionally, single-cell-based traces of cancer cell populations, chromatin accessibility, epigenetic alterations, genome-wide germline mutations, functional non-coding and synonymous mutations, and other abnormalities at the non-genomic levels, such as protein and metabolic levels, are still poorly understood. Information on these aspects can help in drug discovery and improvement in the prognoses of leukemia patients, including BCP-ALLs [103-105,183-188]. Through the comprehensive identification of prognostic biomarkers and the development of new techniques in diagnosis and target treatment, we can further improve the survival time and life quality of patients with BCP-ALL.

\section{Acknowledgements}

This work was supported by the National Natural Science Foundation of China (Nos. 82070147, 81570122, and 81770205), the National Key Research and Development Program (No. 2016YFC0902800), the Shanghai Municipal Education Commission-Gaofeng Clinical Medicine Grant Support (No. 20161303), the Innovation Foundation for Doctoral Students of Shanghai Jiao Tong University School of Medicine (Research Grant BXJ201815), and the Center for HPC at Shanghai Jiao Tong University. The funders had no role in study design, data collection and analysis, decision to publish, or preparation of the manuscript. 


\section{Compliance with ethical guidelines}

Jianfeng Li, Yuting Dai, Liang Wu, Ming Zhang, Wen Ouyang, Jinyan Huang, and Saijuan Chen declare that the research was conducted in the absence of any commercial or financial relationships that could be construed as a potential conflict of interest. This manuscript is a review article and does not involve a research protocol requiring approval by the relevant institutional review board or ethics committee.

Open Access This article is licensed under a Creative Commons Attribution 4.0 International License, which permits use, sharing, adaptation, distribution and reproduction in any medium or format, as long as you give appropriate credit to the original author(s) and the source, provide a link to the Creative Commons license, and indicate if changes were made.

The images or other third party material in this article are included in the article's Creative Commons license, unless indicated otherwise in a credit line to the material. If material is not included in the article's Creative Commons license and your intended use is not permitted by statutory regulation or exceeds the permitted use, you will need to obtain permission directly from the copyright holder.

To view a copy of this license, visit https://creativecommons.org/ licenses/by/4.0/.

\section{References}

1. Hunger SP, Mullighan CG. Acute lymphoblastic leukemia in children. N Engl J Med 2015; 373(16): 1541-1552

2. Pui $\mathrm{CH}$. Genomic and pharmacogenetic studies of childhood acute lymphoblastic leukemia. Front Med 2015; 9(1): 1-9

3. Huang KL, Mashl RJ, Wu Y, Ritter DI, Wang J, Oh C, Paczkowska M, Reynolds S, Wyczalkowski MA, Oak N, Scott AD, Krassowski M, Cherniack AD, Houlahan KE, Jayasinghe R, Wang LB, Zhou DC, Liu D, Cao S, Kim YW, Koire A, McMichael JF, Hucthagowder V, Kim TB, Hahn A, Wang C, McLellan MD, Al-Mulla F, Johnson KJ; Cancer Genome Atlas Research Network, Lichtarge O, Boutros PC, Raphael B, Lazar AJ, Zhang W, Wendl MC, Govindan R, Jain S, Wheeler D, Kulkarni S, Dipersio JF, Reimand J, Meric-Bernstam F, Chen K, Shmulevich I, Plon SE, Chen F, Ding L. Pathogenic germline variants in 10,389 adult cancers. Cell 2018; 173(2): 355-370.e14

4. Stadler ZK, Schrader KA, Vijai J, Robson ME, Offit K. Cancer genomics and inherited risk. J Clin Oncol 2014; 32(7): 687-698

5. Iacobucci I, Mullighan CG. Genetic basis of acute lymphoblastic leukemia. J Clin Oncol 2017; 35(9): 975-983

6. Genovese G, Kähler AK, Handsaker RE, Lindberg J, Rose SA, Bakhoum SF, Chambert K, Mick E, Neale BM, Fromer M, Purcell SM, Svantesson O, Landén M, Höglund M, Lehmann S, Gabriel SB, Moran JL, Lander ES, Sullivan PF, Sklar P, Grönberg H, Hultman CM, McCarroll SA. Clonal hematopoiesis and bloodcancer risk inferred from blood DNA sequence. N Engl J Med 2014; 371(26): 2477-2487

7. Vijayakrishnan J, Qian M, Studd JB, Yang W, Kinnersley B, Law
PJ, Broderick P, Raetz EA, Allan J, Pui CH, Vora A, Evans WE, Moorman A, Yeoh A, Yang W, Li C, Bartram CR, Mullighan CG, Zimmerman M, Hunger SP, Schrappe M, Relling MV, Stanulla M, Loh ML, Houlston RS, Yang JJ. Identification of four novel associations for B-cell acute lymphoblastic leukaemia risk. Nat Commun 2019; 10(1): 5348

8. Li JF, Dai YT, Lilljebjörn H, Shen SH, Cui BW, Bai L, Liu YF, Qian MX, Kubota Y, Kiyoi H, Matsumura I, Miyazaki Y, Olsson L, Tan AM, Ariffin H, Chen J, Takita J, Yasuda T, Mano H, Johansson B, Yang JJ, Yeoh AE, Hayakawa F, Chen Z, Pui CH, Fioretos T, Chen SJ, Huang JY. Transcriptional landscape of B cell precursor acute lymphoblastic leukemia based on an international study of 1,223 cases. Proc Natl Acad Sci USA 2018; 115(50): E11711-E11720

9. Gu Z, Churchman ML, Roberts KG, Moore I, Zhou X, Nakitandwe J, Hagiwara K, Pelletier S, Gingras S, Berns H, Payne-Turner D, Hill A, Iacobucci I, Shi L, Pounds S, Cheng C, Pei D, Qu C, Newman S, Devidas M, Dai Y, Reshmi SC, Gastier-Foster J, Raetz EA, Borowitz MJ, Wood BL, Carroll WL, Zweidler-McKay PA, Rabin KR, Mattano LA, Maloney KW, Rambaldi A, Spinelli O, Radich JP, Minden MD, Rowe JM, Luger S, Litzow MR, Tallman MS, Racevskis J, Zhang Y, Bhatia R, Kohlschmidt J, Mrózek K, Bloomfield CD, Stock W, Kornblau S, Kantarjian HM, Konopleva M, Evans WE, Jeha S, Pui CH, Yang J, Paietta E, Downing JR, Relling MV, Zhang J, Loh ML, Hunger SP, Mullighan CG. PAX5driven subtypes of B-progenitor acute lymphoblastic leukemia. Nat Genet 2019; 51(2): 296-307

10. Pui CH, Tang JY, Yang JJ, Chen SJ, Chen Z. International collaboration to save children with acute lymphoblastic leukemia. J Glob Oncol 2019; 5(5): 1-2

11. Pui CH, Yang JJ, Bhakta N, Rodriguez-Galindo C. Global efforts toward the cure of childhood acute lymphoblastic leukaemia. Lancet Child Adolesc Health 2018; 2(6): 440-454

12. Teachey DT, Pui CH. Comparative features and outcomes between paediatric T-cell and B-cell acute lymphoblastic leukaemia. Lancet Oncol 2019; 20(3): e142-e154

13. Bassan R, Bourquin JP, DeAngelo DJ, Chiaretti S. New approaches to the management of adult acute lymphoblastic leukemia. J Clin Oncol 2018; 36(35): 3504-3519

14. Li B, Li H, Bai Y, Kirschner-Schwabe R, Yang JJ, Chen Y, Lu G, Tzoneva G, Ma X, Wu T, Li W, Lu H, Ding L, Liang H, Huang X, Yang M, Jin L, Kang H, Chen S, Du A, Shen S, Ding J, Chen H, Chen J, von Stackelberg A, Gu L, Zhang J, Ferrando A, Tang J, Wang S, Zhou BB. Negative feedback-defective PRPS1 mutants drive thiopurine resistance in relapsed childhood ALL. Nat Med 2015; 21(6): 563-571

15. Ohki K, Kiyokawa N, Saito Y, Hirabayashi S, Nakabayashi K, Ichikawa H, Momozawa Y, Okamura K, Yoshimi A, OgataKawata H, Sakamoto H, Kato M, Fukushima K, Hasegawa D, Fukushima H, Imai M, Kajiwara R, Koike T, Komori I, Matsui A, Mori M, Moriwaki K, Noguchi Y, Park MJ, Ueda T, Yamamoto S, Matsuda K, Yoshida T, Matsumoto K, Hata K, Kubo M, Matsubara Y, Takahashi H, Fukushima T, Hayashi Y, Koh K, Manabe A, Ohara A, Tokyo Children's Cancer Study Group (TCCSG). Clinical and molecular characteristics of $M E F 2 D$ fusion-positive B-cell precursor acute lymphoblastic leukemia in childhood, including a novel translocation resulting in MEF2D-HNRNPH1 gene fusion. Haematologica 2019; 104(1): 128-137 
16. Gu Z, Churchman M, Roberts K, Li Y, Liu Y, Harvey RC, McCastlain K, Reshmi SC, Payne-Turner D, Iacobucci I, Shao Y, Chen IM, Valentine M, Pei D, Mungall KL, Mungall AJ, Ma Y, Moore R, Marra M, Stonerock E, Gastier-Foster JM, Devidas M, Dai Y, Wood B, Borowitz M, Larsen EE, Maloney K, Mattano LA Jr, Angiolillo A, Salzer WL, Burke MJ, Gianni F, Spinelli O, Radich JP, Minden MD, Moorman AV, Patel B, Fielding AK, Rowe JM, Luger SM, Bhatia R, Aldoss I, Forman SJ, Kohlschmidt J, Mrózek K, Marcucci G, Bloomfield CD, Stock W, Kornblau S, Kantarjian HM, Konopleva M, Paietta E, Willman CL, Loh ML, Hunger SP, Mullighan CG. Genomic analyses identify recurrent MEF2D fusions in acute lymphoblastic leukaemia. Nat Commun 2016; 7: 13331

17. Lilljebjörn H, Henningsson R, Hyrenius-Wittsten A, Olsson L, Orsmark-Pietras C, von Palffy S, Askmyr M, Rissler M, Schrappe M, Cario G, Castor A, Pronk CJ, Behrendtz M, Mitelman F, Johansson B, Paulsson K, Andersson AK, Fontes M, Fioretos T. Identification of ETV6-RUNX1-like and DUX4-rearranged subtypes in paediatric B-cell precursor acute lymphoblastic leukaemia. Nat Commun 2016; 7(1): 11790

18. Liu YF, Wang BY, Zhang WN, Huang JY, Li BS, Zhang M, Jiang L, Li JF, Wang MJ, Dai YJ, Zhang ZG, Wang Q, Kong J, Chen B, Zhu YM, Weng XQ, Shen ZX, Li JM, Wang J, Yan XJ, Li Y, Liang YM, Liu L, Chen XQ, Zhang WG, Yan JS, Hu JD, Shen SH, Chen J, Gu LJ, Pei D, Li Y, Wu G, Zhou X, Ren RB, Cheng C, Yang JJ, Wang KK, Wang SY, Zhang J, Mi JQ, Pui CH, Tang JY, Chen Z, Chen SJ. Genomic profiling of adult and pediatric B-cell acute lymphoblastic leukemia. EBioMedicine 2016; 8: 173-183

19. Arber DA, Orazi A, Hasserjian R, Thiele J, Borowitz MJ, Le Beau MM, Bloomfield CD, Cazzola M, Vardiman JW. The 2016 revision to the World Health Organization classification of myeloid neoplasms and acute leukemia. Blood 2016; 127(20): 2391-2405

20. Yasuda T, Tsuzuki S, Kawazu M, Hayakawa F, Kojima S, Ueno T, Imoto N, Kohsaka S, Kunita A, Doi K, Sakura T, Yujiri T, Kondo E, Fujimaki K, Ueda Y, Aoyama Y, Ohtake S, Takita J, Sai E, Taniwaki M, Kurokawa M, Morishita S, Fukayama M, Kiyoi H, Miyazaki Y, Naoe T, Mano H. Recurrent DUX4 fusions in B cell acute lymphoblastic leukemia of adolescents and young adults. Nat Genet 2016; 48(5): 569-574

21. Zhang J, McCastlain K, Yoshihara H, Xu B, Chang Y, Churchman ML, Wu G, Li Y, Wei L, Iacobucci I, Liu Y, Qu C, Wen J, Edmonson M, Payne-Turner D, Kaufmann KB, Takayanagi SI, Wienholds E, Waanders E, Ntziachristos P, Bakogianni S, Wang J, Aifantis I, Roberts KG, Ma J, Song G, Easton J, Mulder HL, Chen X, Newman S, Ma X, Rusch M, Gupta P, Boggs K, Vadodaria B, Dalton J, Liu Y, Valentine ML, Ding L, Lu C, Fulton RS, Fulton L, Tabib Y, Ochoa K, Devidas M, Pei D, Cheng C, Yang J, Evans WE, Relling MV, Pui CH, Jeha S, Harvey RC, Chen IL, Willman CL, Marcucci G, Bloomfield CD, Kohlschmidt J, Mrózek K, Paietta E, Tallman MS, Stock W, Foster MC, Racevskis J, Rowe JM, Luger S, Kornblau SM, Shurtleff SA, Raimondi SC, Mardis ER, Wilson RK, Dick JE, Hunger SP, Loh ML, Downing JR, Mullighan CG, St. Jude Children's Research Hospital-Washington University Pediatric Cancer Genome Project. Deregulation of DUX4 and ERG in acute lymphoblastic leukemia. Nat Genet 2016; 48(12): 1481-1489

22. Qian M, Zhang H, Kham SK, Liu S, Jiang C, Zhao X, Lu Y, Goodings C, Lin TN, Zhang R, Moriyama T, Yin Z, Li Z, Quah
TC, Ariffin H, Tan AM, Shen S, Bhojwani D, Hu S, Chen S, Zheng $\mathrm{H}$, Pui $\mathrm{CH}$, Yeoh AE, Yang JJ. Whole-transcriptome sequencing identifies a distinct subtype of acute lymphoblastic leukemia with predominant genomic abnormalities of EP300 and CREBBP. Genome Res 2017; 27(2): 185-195

23. Holmfeldt L, Wei L, Diaz-Flores E, Walsh M, Zhang J, Ding L, Payne-Turner D, Churchman M, Andersson A, Chen SC, McCastlain K, Becksfort J, Ma J, Wu G, Patel SN, Heatley SL, Phillips LA, Song G, Easton J, Parker M, Chen X, Rusch M, Boggs K, Vadodaria B, Hedlund E, Drenberg C, Baker S, Pei D, Cheng C, Huether R, Lu C, Fulton RS, Fulton LL, Tabib Y, Dooling DJ, Ochoa K, Minden M, Lewis ID, To LB, Marlton P, Roberts AW, Raca G, Stock W, Neale G, Drexler HG, Dickins RA, Ellison DW, Shurtleff SA, Pui CH, Ribeiro RC, Devidas M, Carroll AJ, Heerema NA, Wood B, Borowitz MJ, Gastier-Foster JM, Raimondi SC, Mardis ER, Wilson RK, Downing JR, Hunger SP, Loh ML, Mullighan CG. The genomic landscape of hypodiploid acute lymphoblastic leukemia. Nat Genet 2013; 45(3): 242-252

24. Andersson AK, Ma J, Wang J, Chen X, Gedman AL, Dang J, Nakitandwe J, Holmfeldt L, Parker M, Easton J, Huether R, Kriwacki R, Rusch M, Wu G, Li Y, Mulder H, Raimondi S, Pounds S, Kang G, Shi L, Becksfort J, Gupta P, Payne-Turner D, Vadodaria B, Boggs K, Yergeau D, Manne J, Song G, Edmonson M, Nagahawatte P, Wei L, Cheng C, Pei D, Sutton R, Venn NC, Chetcuti A, Rush A, Catchpoole D, Heldrup J, Fioretos T, Lu C, Ding L, Pui CH, Shurtleff S, Mullighan CG, Mardis ER, Wilson RK, Gruber TA, Zhang J, Downing JR, St. Jude Children's Research Hospital-Washington University Pediatric Cancer Genome Project. The landscape of somatic mutations in infant MLLrearranged acute lymphoblastic leukemias. Nat Genet 2015; 47(4): 330-337

25. Fischer U, Forster M, Rinaldi A, Risch T, Sungalee S, Warnatz HJ, Bornhauser B, Gombert M, Kratsch C, Stütz AM, Sultan M, Tchinda J, Worth CL, Amstislavskiy V, Badarinarayan N, Baruchel A, Bartram T, Basso G, Canpolat C, Cario G, Cavé H, Dakaj D, Delorenzi M, Dobay MP, Eckert C, Ellinghaus E, Eugster S, Frismantas V, Ginzel S, Haas OA, Heidenreich O, HemmrichStanisak G, Hezaveh K, Höll JI, Hornhardt S, Husemann P, Kachroo P, Kratz CP, Te Kronnie G, Marovca B, Niggli F, McHardy AC, Moorman AV, Panzer-Grümayer R, Petersen BS, Raeder B, Ralser M, Rosenstiel P, Schäfer D, Schrappe M, Schreiber S, Schütte M, Stade B, Thiele R, von der Weid N, Vora A, Zaliova M, Zhang L, Zichner T, Zimmermann M, Lehrach H, Borkhardt A, Bourquin JP, Franke A, Korbel JO, Stanulla M, Yaspo ML. Genomics and drug profiling of fatal TCF3-HLFpositive acute lymphoblastic leukemia identifies recurrent mutation patterns and therapeutic options. Nat Genet 2015; 47(9): 10201029

26. Zaliova M, Stuchly J, Winkowska L, Musilova A, Fiser K, Slamova M, Starkova J, Vaskova M, Hrusak O, Sramkova L, Stary J, Zuna J, Trka J. Genomic landscape of pediatric B-other acute lymphoblastic leukemia in a consecutive European cohort. Haematologica 2019; 104(7): 1396-1406

27. Pui CH, Nichols KE, Yang JJ. Somatic and germline genomics in paediatric acute lymphoblastic leukaemia. Nat Rev Clin Oncol 2019; 16(4): 227-240

28. Bonaventure A, Harewood R, Stiller CA, Gatta G, Clavel J, Stefan DC, Carreira H, Spika D, Marcos-Gragera R, Peris-Bonet R, 
Piñeros M, Sant M, Kuehni CE, Murphy MFG, Coleman MP, Allemani C, CONCORD Working Group. Worldwide comparison of survival from childhood leukaemia for 1995-2009, by subtype, age, and sex (CONCORD-2): a population-based study of individual data for 89828 children from 198 registries in 53 countries. Lancet Haematol 2017; 4(5): e202-e217

29. Yeoh AE, Ariffin H, Chai EL, Kwok CS, Chan YH, Ponnudurai K, Campana D, Tan PL, Chan MY, Kham SK, Chong LA, Tan AM, Lin HP, Quah TC. Minimal residual disease-guided treatment deintensification for children with acute lymphoblastic leukemia: results from the Malaysia-Singapore acute lymphoblastic leukemia 2003 study. J Clin Oncol 2012; 30(19): 2384-2392

30. Vora A, Goulden N, Mitchell C, Hancock J, Hough R, Rowntree C, Moorman AV, Wade R. Augmented post-remission therapy for a minimal residual disease-defined high-risk subgroup of children and young people with clinical standard-risk and intermediate-risk acute lymphoblastic leukaemia (UKALL 2003): a randomised controlled trial. Lancet Oncol 2014; 15(8): 809-818

31. Toft N, Birgens H, Abrahamsson J, Griškevičius L, Hallböök H, Heyman M, Klausen TW, Jónsson OG, Palk K, Pruunsild K, QuistPaulsen P, Vaitkeviciene G, Vettenranta K, Åsberg A, Frandsen TL, Marquart HV, Madsen HO, Norén-Nyström U, Schmiegelow K. Results of NOPHO ALL2008 treatment for patients aged 1-45 years with acute lymphoblastic leukemia. Leukemia 2018; 32(3): 606-615

32. Pui CH, Pei D, Coustan-Smith E, Jeha S, Cheng C, Bowman WP, Sandlund JT, Ribeiro RC, Rubnitz JE, Inaba H, Bhojwani D, Gruber TA, Leung WH, Downing JR, Evans WE, Relling MV, Campana D. Clinical utility of sequential minimal residual disease measurements in the context of risk-based therapy in childhood acute lymphoblastic leukaemia: a prospective study. Lancet Oncol 2015; 16(4): 465-474

33. Pui CH, Pei D, Campana D, Cheng C, Sandlund JT, Bowman WP, Hudson MM, Ribeiro RC, Raimondi SC, Jeha S, Howard SC, Bhojwani D, Inaba H, Rubnitz JE, Metzger ML, Gruber TA, Coustan-Smith E, Downing JR, Leung WH, Relling MV, Evans WE. A revised definition for cure of childhood acute lymphoblastic leukemia. Leukemia 2014; 28(12): 2336-2343

34. Place AE, Stevenson KE, Vrooman LM, Harris MH, Hunt SK, O'Brien JE, Supko JG, Asselin BL, Athale UH, Clavell LA, Cole PD, Kelly KM, Laverdiere C, Leclerc JM, Michon B, Schorin MA, Welch JJ, Lipshultz SE, Kutok JL, Blonquist TM, Neuberg DS, Sallan SE, Silverman LB. Intravenous pegylated asparaginase versus intramuscular native Escherichia coli L-asparaginase in newly diagnosed childhood acute lymphoblastic leukaemia (DFCI 05-001): a randomised, open-label phase 3 trial. Lancet Oncol 2015; 16(16): 1677-1690

35. Pieters R, de Groot-Kruseman H, Van der Velden V, Fiocco M, van den Berg H, de Bont E, Egeler RM, Hoogerbrugge P, Kaspers G, Van der Schoot E, De Haas V, Van Dongen J. Successful therapy reduction and intensification for childhood acute lymphoblastic leukemia based on minimal residual disease monitoring: Study ALL10 From the Dutch Childhood Oncology Group. J Clin Oncol 2016; 34(22): 2591-2601

36. Hunger SP, Lu X, Devidas M, Camitta BM, Gaynon PS, Winick NJ, Reaman GH, Carroll WL. Improved survival for children and adolescents with acute lymphoblastic leukemia between 1990 and 2005: a report from the children's oncology group. J Clin Oncol
2012; 30(14): 1663-1669

37. Domenech C, Suciu S, De Moerloose B, Mazingue F, Plat G, Ferster A, Uyttebroeck A, Sirvent N, Lutz P, Yakouben K, Munzer M, Röhrlich P, Plantaz D, Millot F, Philippet P, Dastugue N, Girard S, Cavé H, Benoit Y, Bertrandfor Y, Children's Leukemia Group (CLG) of European Organisation for Research and Treatment of Cancer (EORTC). Dexamethasone $\left(6 \mathrm{mg} / \mathrm{m}^{2} /\right.$ day) and prednisolone $\left(60 \mathrm{mg} / \mathrm{m}^{2} /\right.$ day $)$ were equally effective as induction therapy for childhood acute lymphoblastic leukemia in the EORTC CLG 58951 randomized trial. Haematologica 2014; 99 (7): 1220-1227

38. Conter V, Bartram CR, Valsecchi MG, Schrauder A, PanzerGrümayer R, Möricke A, Aricò M, Zimmermann M, Mann G, De Rossi G, Stanulla M, Locatelli F, Basso G, Niggli F, Barisone E, Henze G, Ludwig WD, Haas OA, Cazzaniga G, Koehler R, Silvestri D, Bradtke J, Parasole R, Beier R, van Dongen JJ, Biondi A, Schrappe M. Molecular response to treatment redefines all prognostic factors in children and adolescents with B-cell precursor acute lymphoblastic leukemia: results in 3184 patients of the AIEOP-BFM ALL 2000 study. Blood 2010; 115(16): 32063214

39. Pui CH, Campana D, Pei D, Bowman WP, Sandlund JT, Kaste SC, Ribeiro RC, Rubnitz JE, Raimondi SC, Onciu M, Coustan-Smith E, Kun LE, Jeha S, Cheng C, Howard SC, Simmons V, Bayles A, Metzger ML, Boyett JM, Leung W, Handgretinger R, Downing JR, Evans WE, Relling MV. Treating childhood acute lymphoblastic leukemia without cranial irradiation. N Engl J Med 2009; 360(26): 2730-2741

40. Pedrosa F, Coustan-Smith E, Zhou Y, Cheng C, Pedrosa A, Lins MM, Pedrosa M, Lucena-Silva N, Ramos AML, Vinhas E, Rivera GK, Campana D, Ribeiro RC. Reduced-dose intensity therapy for pediatric lymphoblastic leukemia: long-term results of the Recife RELLA05 pilot study. Blood 2020; 135(17): 1458-1466

41. Eckert C, Groeneveld-Krentz S, Kirschner-Schwabe R, Hagedorn N, Chen-Santel C, Bader P, Borkhardt A, Cario G, Escherich G, Panzer-Grümayer R, Astrahantseff K, Eggert A, Sramkova L, Attarbaschi A, Bourquin JP, Peters C, Henze G, von Stackelberg A, ALL-REZ BFM Trial Group. Improving stratification for children with late bone marrow B-cell acute lymphoblastic leukemia relapses with refined response classification and integration of genetics. J Clin Oncol 2019; 37(36): 3493-3506

42. Winick N, Martin PL, Devidas M, Shuster J, Borowitz MJ, Paul Bowman W, Larsen E, Pullen J, Carroll A, Willman C, Hunger SP, Carroll WL, Camitta BM. Randomized assessment of delayed intensification and two methods for parenteral methotrexate delivery in childhood B-ALL: Children's Oncology Group Studies P9904 and P9905. Leukemia 2020; 34(4): 1006-1016

43. Coccaro N, Anelli L, Zagaria A, Specchia G, Albano F. Nextgeneration sequencing in acute lymphoblastic leukemia. Int J Mol Sci 2019; 20(12): 2929

44. Churchman ML, Low J, Qu C, Paietta EM, Kasper LH, Chang Y, Payne-Turner D, Althoff MJ, Song G, Chen SC, Ma J, Rusch M, McGoldrick D, Edmonson M, Gupta P, Wang YD, Caufield W, Freeman B, Li L, Panetta JC, Baker S, Yang YL, Roberts KG, McCastlain K, Iacobucci I, Peters JL, Centonze VE, Notta F, Dobson SM, Zandi S, Dick JE, Janke L, Peng J, Kodali K, Pagala V, Min J, Mayasundari A, Williams RT, Willman CL, Rowe J, Luger S, Dickins RA, Guy RK, Chen T, Mullighan CG. Efficacy of 
retinoids in IKZF1-mutated BCR-ABL1 acute lymphoblastic leukemia. Cancer Cell 2015; 28(3): 343-356

45. Gu S, Sayad A, Chan G, Yang W, Lu Z, Virtanen C, Van Etten RA, Neel BG. SHP2 is required for BCR-ABL1-induced hematologic neoplasia. Leukemia 2018; 32(1): 203-213

46. Pfeifer H, Cazzaniga G, van der Velden VHJ, Cayuela JM, Schäfer B, Spinelli O, Akiki S, Avigad S, Bendit I, Borg K, Cavé H, Elia L, Reshmi SC, Gerrard G, Hayette S, Hermanson M, Juh A, Jurcek T, Chillón MC, Homburg C, Martinelli G, Kairisto V, Lange T, Lion T, Mueller MC, Pane F, Rai L, Damm-Welk C, Sacha T, Schnittger $\mathrm{S}$, Touloumenidou T, Valerhaugen $\mathrm{H}$, Vandenberghe P, Zuna J, Serve H, Herrmann E, Markovic S, Dongen JJMV, Ottmann OG. Standardisation and consensus guidelines for minimal residual disease assessment in Philadelphia-positive acute lymphoblastic leukemia $\left(\mathrm{Ph}^{+} \mathrm{ALL}\right)$ by real-time quantitative reverse transcriptase PCR of ela2 BCR-ABL1. Leukemia 2019; 33(8): 1910-1922

47. Baccarani M, Castagnetti F, Gugliotta G, Rosti G, Soverini S, Albeer A, Pfirrmann M, International BCR-ABL Study Group. The proportion of different BCR-ABL1 transcript types in chronic myeloid leukemia. An international overview. Leukemia 2019; 33 (5): 1173-1183

48. Su Z, Wu F, Hu W, Liu X, Wu S, Feng X, Cui Z, Yang J, Wang Z, Guan H, Zhao H, Wang W, Zhao C, Peng J. Philadelphia chromosome-positive acute myeloid leukemia with masses and osteolytic lesions: finding of 18F-FDG PET/CT. Front Med 2017; 11(3): 440-444

49. Mullighan CG, Miller CB, Radtke I, Phillips LA, Dalton J, Ma J, White D, Hughes TP, Le Beau MM, Pui CH, Relling MV, Shurtleff SA, Downing JR. BCR-ABL1 lymphoblastic leukaemia is characterized by the deletion of Ikaros. Nature 2008; 453(7191): $110-114$

50. Lou Y, Ma Y, Li C, Suo S, Tong H, Qian W, Mai W, Meng H, Yu W, Mao L, Wei J, Xu W, Jin J. Efficacy and prognostic factors of imatinib plus CALLG2008 protocol in adult patients with newly diagnosed Philadelphia chromosome-positive acute lymphoblastic leukemia. Front Med 2017; 11(2): 229-238

51. Chen CW, Koche RP, Sinha AU, Deshpande AJ, Zhu N, Eng R, Doench JG, Xu H, Chu SH, Qi J, Wang X, Delaney C, Bernt KM, Root DE, Hahn WC, Bradner JE, Armstrong SA. DOT1L inhibits SIRT1-mediated epigenetic silencing to maintain leukemic gene expression in MLL-rearranged leukemia. Nat Med 2015; 21(4): 335-343

52. Meyer C, Hofmann J, Burmeister T, Gröger D, Park TS, Emerenciano M, Pombo de Oliveira M, Renneville A, Villarese P, Macintyre E, Cavé H, Clappier E, Mass-Malo K, Zuna J, Trka J, De Braekeleer E, De Braekeleer M, Oh SH, Tsaur G, Fechina L, van der Velden VH, van Dongen JJ, Delabesse E, Binato R, Silva ML, Kustanovich A, Aleinikova O, Harris MH, Lund-Aho T, Juvonen V, Heidenreich O, Vormoor J, Choi WW, Jarosova M, Kolenova A, Bueno C, Menendez P, Wehner S, Eckert C, Talmant P, Tondeur S, Lippert E, Launay E, Henry C, Ballerini P, Lapillone H, Callanan MB, Cayuela JM, Herbaux C, Cazzaniga G, Kakadiya PM, Bohlander S, Ahlmann M, Choi JR, Gameiro P, Lee DS, Krauter J, Cornillet-Lefebvre P, Te Kronnie G, Schäfer BW, Kubetzko S, Alonso CN, zur Stadt U, Sutton R, Venn NC, Izraeli S, Trakhtenbrot L, Madsen HO, Archer P, Hancock J, Cerveira N, Teixeira MR, Lo Nigro L, Möricke A, Stanulla M, Schrappe M, Sedék L, Szczepański T, Zwaan CM, Coenen EA, van den Heuvel-
Eibrink MM, Strehl S, Dworzak M, Panzer-Grümayer R, Dingermann T, Klingebiel T, Marschalek R. The MLL recombinome of acute leukemias in 2013. Leukemia 2013; 27(11): 21652176

53. Sanjuan-Pla A, Bueno C, Prieto C, Acha P, Stam RW, Marschalek $\mathrm{R}$, Menéndez $\mathrm{P}$. Revisiting the biology of infant $\mathrm{t}(4 ; 11)$ /MLL$\mathrm{AF} 4{ }^{+}$B-cell acute lymphoblastic leukemia. Blood 2015; 126(25): 2676-2685

54. Burmeister T, Gökbuget N, Schwartz S, Fischer L, Hubert D, Sindram A, Hoelzer D, Thiel E. Clinical features and prognostic implications of TCF3-PBX1 and ETV6-RUNX1 in adult acute lymphoblastic leukemia. Haematologica 2010; 95(2): 241-246

55. Papaemmanuil E, Rapado I, Li Y, Potter NE, Wedge DC, Tubio J, Alexandrov LB, Van Loo P, Cooke SL, Marshall J, Martincorena I, Hinton J, Gundem G, van Delft FW, Nik-Zainal S, Jones DR, Ramakrishna M, Titley I, Stebbings L, Leroy C, Menzies A, Gamble J, Robinson B, Mudie L, Raine K, O’Meara S, Teague JW, Butler AP, Cazzaniga G, Biondi A, Zuna J, Kempski H, Muschen M, Ford AM, Stratton MR, Greaves M, Campbell PJ. RAGmediated recombination is the predominant driver of oncogenic rearrangement in ETV6-RUNX1 acute lymphoblastic leukemia. Nat Genet 2014; 46(2): 116-125

56. Schäfer D, Olsen M, Lähnemann D, Stanulla M, Slany R, Schmiegelow K, Borkhardt A, Fischer U. Five percent of healthy newborns have an ETV6-RUNX1 fusion as revealed by DNA-based GIPFEL screening. Blood 2018; 131(7): 821-826

57. Inaba T, Roberts WM, Shapiro LH, Jolly KW, Raimondi SC, Smith SD, Look AT. Fusion of the leucine zipper gene HLF to the E2A gene in human acute B-lineage leukemia. Science 1992; 257 (5069): 531-534

58. Harewood L, Robinson H, Harris R, Al-Obaidi MJ, Jalali GR, Martineau M, Moorman AV, Sumption N, Richards S, Mitchell C, Harrison CJ. Amplification of AML1 on a duplicated chromosome 21 in acute lymphoblastic leukemia: a study of 20 cases. Leukemia 2003; 17(3): 547-553

59. Harrison CJ. Blood spotlight on iAMP21 acute lymphoblastic leukemia (ALL), a high-risk pediatric disease. Blood 2015; 125(9): 1383-1386

60. Moorman AV, Robinson H, Schwab C, Richards SM, Hancock J, Mitchell CD, Goulden N, Vora A, Harrison CJ. Risk-directed treatment intensification significantly reduces the risk of relapse among children and adolescents with acute lymphoblastic leukemia and intrachromosomal amplification of chromosome 21: a comparison of the MRC ALL97/99 and UKALL2003 trials. J Clin Oncol 2013; 31(27): 3389-3396

61. Wylie AA, Schoepfer J, Jahnke W, Cowan-Jacob SW, Loo A, Furet P, Marzinzik AL, Pelle X, Donovan J, Zhu W, Buonamici S, Hassan AQ, Lombardo F, Iyer V, Palmer M, Berellini G, Dodd S, Thohan S, Bitter H, Branford S, Ross DM, Hughes TP, Petruzzelli L, Vanasse KG, Warmuth M, Hofmann F, Keen NJ, Sellers WR. The allosteric inhibitor ABL001 enables dual targeting of BCRABL1. Nature 2017; 543(7647): 733-737

62. Bullinger L, Döhner K, Döhner H. Genomics of acute myeloid leukemia diagnosis and pathways. J Clin Oncol 2017; 35(9): 934946

63. Alexander TB, Gu Z, Iacobucci I, Dickerson K, Choi JK, Xu B, Payne-Turner D, Yoshihara H, Loh ML, Horan J, Buldini B, Basso G, Elitzur S, de Haas V, Zwaan CM, Yeoh A, Reinhardt D, 
Tomizawa D, Kiyokawa N, Lammens T, De Moerloose B, Catchpoole D, Hori H, Moorman A, Moore AS, Hrusak O, Meshinchi S, Orgel E, Devidas M, Borowitz M, Wood B, Heerema NA, Carrol A, Yang YL, Smith MA, Davidsen TM, Hermida LC, Gesuwan P, Marra MA, Ma Y, Mungall AJ, Moore RA, Jones SJM, Valentine M, Janke LJ, Rubnitz JE, Pui CH, Ding L, Liu Y, Zhang J, Nichols KE, Downing JR, Cao X, Shi L, Pounds S, Newman S, Pei D, Guidry Auvil JM, Gerhard DS, Hunger SP, Inaba $\mathrm{H}$, Mullighan $\mathrm{CG}$. The genetic basis and cell of origin of mixed phenotype acute leukaemia. Nature 2018; 562(7727): 373379

64. Suzuki K, Okuno Y, Kawashima N, Muramatsu H, Okuno T, Wang X, Kataoka S, Sekiya Y, Hamada M, Murakami N, Kojima D, Narita K, Narita A, Sakaguchi H, Sakaguchi K, Yoshida N, Nishio N, Hama A, Takahashi Y, Kudo K, Kato K, Kojima S. MEF2D-BCL9 fusion gene is associated with high-risk acute Bcell precursor lymphoblastic leukemia in adolescents. J Clin Oncol 2016; 34(28): 3451-3459

65. Bastian L, Schroeder MP, Eckert C, Schlee C, Tanchez JO, Kämpf $\mathrm{S}$, Wagner DL, Schulze V, Isaakidis K, Lázaro-Navarro J, Hänzelmann S, James AR, Ekici A, Burmeister T, Schwartz S, Schrappe M, Horstmann M, Vosberg S, Krebs S, Blum H, Hecht J, Greif PA, Rieger MA, Brüggemann M, Gökbuget N, Neumann M, Baldus CD. PAX5 biallelic genomic alterations define a novel subgroup of B-cell precursor acute lymphoblastic leukemia. Leukemia 2019; 33(8): 1895-1909

66. McClure BJ, Heatley SL, Kok CH, Sadras T, An J, Hughes TP, Lock RB, Yeung D, Sutton R, White DL. Pre-B acute lymphoblastic leukaemia recurrent fusion, EP300-ZNF384, is associated with a distinct gene expression. Br J Cancer 2018; 118 (7): 1000-1004

67. Ping N, Qiu H, Wang Q, Dai H, Ruan C, Ehrentraut S, Drexler HG, MacLeod RA, Chen S. Establishment and genetic characterization of a novel mixed-phenotype acute leukemia cell line with EP300ZNF384 fusion. J Hematol Oncol 2015; 8(1): 100

68. Prima V, Hunger SP. Cooperative transformation by MEF2D/ DAZAP1 and DAZAP1/MEF2D fusion proteins generated by the variant $\mathrm{t}(1 ; 19)$ in acute lymphoblastic leukemia. Leukemia 2007; 21(12): 2470-2475

69. Liu L, Leng L, Liu C, Lu C, Yuan Y, Wu L, Gong F, Zhang S, Wei X, Wang M, Zhao L, Hu L, Wang J, Yang H, Zhu S, Chen F, Lu G, Shang Z, Lin G. An integrated chromatin accessibility and transcriptome landscape of human pre-implantation embryos. Nat Commun 2019; 10(1): 364

70. Wu J, Xu J, Liu B, Yao G, Wang P, Lin Z, Huang B, Wang X, Li T, Shi S, Zhang N, Duan F, Ming J, Zhang X, Niu W, Song W, Jin H, Guo Y, Dai S, Hu L, Fang L, Wang Q, Li Y, Li W, Na J, Xie W, Sun Y. Chromatin analysis in human early development reveals epigenetic transition during ZGA. Nature 2018; 557(7704): 256260

71. Dong X, Zhang W, Wu H, Huang J, Zhang M, Wang P, Zhang H, Chen Z, Chen SJ, Meng G. Structural basis of DUX4/IGH-driven transactivation. Leukemia 2018; 32(6): 1466-1476

72. Stanulla M, Dagdan E, Zaliova M, Möricke A, Palmi C, Cazzaniga G, Eckert C, Te Kronnie G, Bourquin JP, Bornhauser B, Koehler R, Bartram CR, Ludwig WD, Bleckmann K, Groeneveld-Krentz S, Schewe D, Junk SV, Hinze L, Klein N, Kratz CP, Biondi A, Borkhardt A, Kulozik A, Muckenthaler MU, Basso G, Valsecchi
MG, Izraeli S, Petersen BS, Franke A, Dörge P, Steinemann D, Haas OA, Panzer-Grümayer R, Cavé H, Houlston RS, Cario G, Schrappe M, Zimmermann M, TRANSCALL Consortium; International BFM Study Group. IKZF1 ${ }^{\text {plus }}$ defines a new minimal residual disease-dependent very-poor prognostic profile in pediatric B-cell precursor acute lymphoblastic leukemia. J Clin Oncol 2018; 36(12): 1240-1249

73. Zaliova M, Potuckova E, Hovorkova L, Musilova A, Winkowska L, Fiser K, Stuchly J, Mejstrikova E, Starkova J, Zuna J, Stary J, Trka J. ERG deletions in childhood acute lymphoblastic leukemia with $D U X 4$ rearrangements are mostly polyclonal, prognostically relevant and their detection rate strongly depends on screening method sensitivity. Haematologica 2019; 104(7): 1407-1416

74. Tian L, Shao Y, Nance S, Dang J, Xu B, Ma X, Li Y, Ju B, Dong L, Newman S, Zhou X, Schreiner P, Tseng E, Hon T, Ashby M, Li C, Easton J, Gruber TA, Zhang J. Long-read sequencing unveils IGHDUX4 translocation into the silenced IGH allele in B-cell acute lymphoblastic leukemia. Nat Commun 2019; 10(1): 2789

75. Yang Q, She H, Gearing M, Colla E, Lee M, Shacka JJ, Mao Z. Regulation of neuronal survival factor MEF2D by chaperonemediated autophagy. Science 2009; 323(5910): 124-127

76. Hirano D, Hayakawa F, Yasuda T, Tange N, Yamamoto H, Kojima Y, Morishita T, Imoto N, Tsuzuki S, Mano H, Naoe T, Kiyoi H. Chromosomal translocation-mediated evasion from miRNA induces strong MEF2D fusion protein expression, causing inhibition of PAX5 transcriptional activity. Oncogene 2019; 38 (13): 2263-2274

77. Chen B, Jiang L, Zhong ML, Li JF, Li BS, Peng LJ, Dai YT, Cui BW, Yan TQ, Zhang WN, Weng XQ, Xie YY, Lu J, Ren RB, Chen SN, Hu JD, Wu DP, Chen Z, Tang JY, Huang JY, Mi JQ, Chen SJ. Identification of fusion genes and characterization of transcriptome features in T-cell acute lymphoblastic leukemia. Proc Natl Acad Sci USA 2018; 115(2): 373-378

78. Homminga I, Pieters R, Langerak AW, de Rooi JJ, Stubbs A, Verstegen M, Vuerhard M, Buijs-Gladdines J, Kooi C, Klous P, van Vlierberghe P, Ferrando AA, Cayuela JM, Verhaaf B, Beverloo HB, Horstmann M, de Haas V, Wiekmeijer AS, PikeOverzet K, Staal FJ, de Laat W, Soulier J, Sigaux F, Meijerink JP. Integrated transcript and genome analyses reveal NKX2-1 and MEF2C as potential oncogenes in $\mathrm{T}$ cell acute lymphoblastic leukemia. Cancer Cell 2011; 19(4): 484-497

79. Ma M, Wang X, Tang J, Xue H, Chen J, Pan C, Jiang H, Shen S. Early T-cell precursor leukemia: a subtype of high risk childhood acute lymphoblastic leukemia. Front Med 2012; 6(4): 416-420

80. Seki M, Kimura S, Isobe T, Yoshida K, Ueno H, Nakajima-Takagi Y, Wang C, Lin L, Kon A, Suzuki H, Shiozawa Y, Kataoka K, Fujii Y, Shiraishi Y, Chiba K, Tanaka H, Shimamura T, Masuda K, Kawamoto H, Ohki K, Kato M, Arakawa Y, Koh K, Hanada R, Moritake H, Akiyama M, Kobayashi R, Deguchi T, Hashii Y, Imamura T, Sato A, Kiyokawa N, Oka A, Hayashi Y, Takagi M, Manabe A, Ohara A, Horibe K, Sanada M, Iwama A, Mano H, Miyano S, Ogawa S, Takita J. Recurrent SPI1 (PU.1) fusions in high-risk pediatric $\mathrm{T}$ cell acute lymphoblastic leukemia. Nat Genet 2017; 49(8): 1274-1281

81. Zhang J, Ding L, Holmfeldt L, Wu G, Heatley SL, Payne-Turner D, Easton J, Chen X, Wang J, Rusch M, Lu C, Chen SC, Wei L, Collins-Underwood JR, Ma J, Roberts KG, Pounds SB, Ulyanov A, Becksfort J, Gupta P, Huether R, Kriwacki RW, Parker M, 
McGoldrick DJ, Zhao D, Alford D, Espy S, Bobba KC, Song G, Pei D, Cheng C, Roberts S, Barbato MI, Campana D, CoustanSmith E, Shurtleff SA, Raimondi SC, Kleppe M, Cools J, Shimano KA, Hermiston ML, Doulatov S, Eppert K, Laurenti E, Notta F, Dick JE, Basso G, Hunger SP, Loh ML, Devidas M, Wood B, Winter S, Dunsmore KP, Fulton RS, Fulton LL, Hong X, Harris CC, Dooling DJ, Ochoa K, Johnson KJ, Obenauer JC, Evans WE, Pui CH, Naeve CW, Ley TJ, Mardis ER, Wilson RK, Downing JR, Mullighan CG. The genetic basis of early T-cell precursor acute lymphoblastic leukaemia. Nature 2012; 481(7380): 157-163

82. Liu Y, Easton J, Shao Y, Maciaszek J, Wang Z, Wilkinson MR, McCastlain K, Edmonson M, Pounds SB, Shi L, Zhou X, Ma X, Sioson E, Li Y, Rusch M, Gupta P, Pei D, Cheng C, Smith MA, Auvil JG, Gerhard DS, Relling MV, Winick NJ, Carroll AJ, Heerema NA, Raetz E, Devidas M, Willman CL, Harvey RC, Carroll WL, Dunsmore KP, Winter SS, Wood BL, Sorrentino BP, Downing JR, Loh ML, Hunger SP, Zhang J, Mullighan CG. The genomic landscape of pediatric and young adult T-lineage acute lymphoblastic leukemia. Nat Genet 2017; 49(8): 1211-1218

83. Prima V, Gore L, Caires A, Boomer T, Yoshinari M, Imaizumi M, Varella-Garcia M, Hunger SP. Cloning and functional characterization of MEF2D/DAZAP1 and DAZAP1/MEF2D fusion proteins created by a variant $\mathrm{t}(1 ; 19)(\mathrm{q} 23 ; \mathrm{p} 13.3)$ in acute lymphoblastic leukemia. Leukemia 2005; 19(5): 806-813

84. Tange N, Hayakawa F, Yasuda T, Odaira K, Yamamoto H, Hirano D, Sakai T, Terakura S, Tsuzuki S, Kiyoi H. Staurosporine and venetoclax induce the caspase-dependent proteolysis of MEF2Dfusion proteins and apoptosis in MEF2D-fusion ${ }^{+}$ALL cells. Biomed Pharmacother 2020; 128: 110330

85. Martini A, La Starza R, Janssen H, Bilhou-Nabera C, Corveleyn A, Somers R, Aventin A, Foà R, Hagemeijer A, Mecucci C, Marynen $P$. Recurrent rearrangement of the Ewing's sarcoma gene, EWSR1, or its homologue, TAF15, with the transcription factor CIZ/NMP4 in acute leukemia. Cancer Res 2002; 62(19): 5408-5412

86. Passet M, Boissel N, Sigaux F, Saillard C, Bargetzi M, Ba I, Thomas X, Graux C, Chalandon Y, Leguay T, Lengliné E, Konopacki J, Quentin S, Delabesse E, Lafage-Pochitaloff M, Pastoret C, Grardel N, Asnafi V, Lhéritier V, Soulier J, Dombret H, Clappier E, Group for Research on Adult ALL (GRAALL). PAX5 P80R mutation identifies a novel subtype of B-cell precursor acute lymphoblastic leukemia with favorable outcome. Blood 2019; 133 (3): 280-284

87. Bueno C, Tejedor JR, Bashford-Rogers R, González-Silva L, Valdés-Mas R, Agraz-Doblás A, Díaz de la Guardia R, Ribera J, Zamora L, Bilhou-Nabera C, Abermil N, Guermouche H, Gouache E, Leverger G, Fraga MF, Fernández AF, Ballerini P, Varela I, Menendez P. Natural history and cell of origin of TCF3-ZNF384 and PTPN11 mutations in monozygotic twins with concordant BCP-ALL. Blood 2019; 134(11): 900-905

88. Savin VJ, Sharma M, Zhou J, Gennochi D, Fields T, Sharma R, McCarthy ET, Srivastava T, Domen J, Tormo A, Gauchat JF. Renal and hematological effects of CLCF-1, a B-cell-stimulating cytokine of the IL-6 family. J Immunol Res 2015; 2015: 714964

89. Den Boer ML, van Slegtenhorst M, De Menezes RX, Cheok MH, Buijs-Gladdines JG, Peters ST, Van Zutven LJ, Beverloo HB, Van der Spek PJ, Escherich G, Horstmann MA, Janka-Schaub GE, Kamps WA, Evans WE, Pieters R. A subtype of childhood acute lymphoblastic leukaemia with poor treatment outcome: a genome- wide classification study. Lancet Oncol 2009; 10(2): 125-134

90. Roberts KG, Morin RD, Zhang J, Hirst M, Zhao Y, Su X, Chen SC, Payne-Turner D, Churchman ML, Harvey RC, Chen X, Kasap C, Yan C, Becksfort J, Finney RP, Teachey DT, Maude SL, Tse K, Moore R, Jones S, Mungall K, Birol I, Edmonson MN, Hu Y, Buetow KE, Chen IM, Carroll WL, Wei L, Ma J, Kleppe M, Levine RL, Garcia-Manero G, Larsen E, Shah NP, Devidas M, Reaman G, Smith M, Paugh SW, Evans WE, Grupp SA, Jeha S, Pui CH, Gerhard DS, Downing JR, Willman CL, Loh M, Hunger SP, Marra MA, Mullighan CG. Genetic alterations activating kinase and cytokine receptor signaling in high-risk acute lymphoblastic leukemia. Cancer Cell 2012; 22(2): 153-166

91. Roberts KG, Li Y, Payne-Turner D, Harvey RC, Yang YL, Pei D, McCastlain K, Ding L, Lu C, Song G, Ma J, Becksfort J, Rusch M, Chen SC, Easton J, Cheng J, Boggs K, Santiago-Morales N, Iacobucci I, Fulton RS, Wen J, Valentine M, Cheng C, Paugh SW, Devidas M, Chen IM, Reshmi S, Smith A, Hedlund E, Gupta P, Nagahawatte P, Wu G, Chen X, Yergeau D, Vadodaria B, Mulder H, Winick NJ, Larsen EC, Carroll WL, Heerema NA, Carroll AJ, Grayson G, Tasian SK, Moore AS, Keller F, Frei-Jones M, Whitlock JA, Raetz EA, White DL, Hughes TP, Guidry Auvil JM, Smith MA, Marcucci G, Bloomfield CD, Mrózek K, Kohlschmidt J, Stock W, Kornblau SM, Konopleva M, Paietta E, Pui CH, Jeha S, Relling MV, Evans WE, Gerhard DS, Gastier-Foster JM, Mardis E, Wilson RK, Loh ML, Downing JR, Hunger SP, Willman CL, Zhang J, Mullighan CG. Targetable kinase-activating lesions in Phlike acute lymphoblastic leukemia. N Engl J Med 2014; 371(11): 1005-1015

92. Hurtz C, Wertheim GB, Loftus JP, Blumenthal D, Lehman A, Li Y, Bagashev A, Manning B, Cummins KD, Burkhardt JK, Perl AE, Carroll M, Tasian SK. Oncogene-independent BCR-like signaling adaptation confers drug resistance in Ph-like ALL. J Clin Invest 2020; 130(7): 3637-3653

93. Sánchez R, Ribera J, Morgades M, Ayala R, Onecha E, RuizHeredia Y, Juárez-Rufián A, de Nicolás R, Sánchez-Pina J, Vives S, Zamora L, Mercadal S, Coll R, Cervera M, García O, Ribera JM, Martínez-López J. A novel targeted RNA-Seq panel identifies a subset of adult patients with acute lymphoblastic leukemia with BCR-ABL1-like characteristics. Blood Cancer J 2020; 10(4): 43

94. Tong J, Flavell RA, Li HB. RNA $\mathrm{m}^{6} \mathrm{~A}$ modification and its function in diseases. Front Med 2018; 12(4): 481-489

95. Rheinbay E, Nielsen MM, Abascal F, Wala JA, Shapira O, Tiao G, Hornshøj H, Hess JM, Juul RI, Lin Z, Feuerbach L, Sabarinathan R, Madsen T, Kim J, Mularoni L, Shuai S, Lanzós A, Herrmann C, Maruvka YE, Shen C, Amin SB, Bandopadhayay P, Bertl J, Boroevich KA, Busanovich J, Carlevaro-Fita J, Chakravarty D, Chan CWY, Craft D, Dhingra P, Diamanti K, Fonseca NA, Gonzalez-Perez A, Guo Q, Hamilton MP, Haradhvala NJ, Hong C, Isaev K, Johnson TA, Juul M, Kahles A, Kahraman A, Kim Y, Komorowski J, Kumar K, Kumar S, Lee D, Lehmann KV, Li Y, Liu EM, Lochovsky L, Park K, Pich O, Roberts ND, Saksena G, Schumacher SE, Sidiropoulos N, Sieverling L, Sinnott-Armstrong N, Stewart C, Tamborero D, Tubio JMC, Umer HM, UuskülaReimand L, Wadelius C, Wadi L, Yao X, Zhang CZ, Zhang J, Haber JE, Hobolth A, Imielinski M, Kellis M, Lawrence MS, von Mering C, Nakagawa H, Raphael BJ, Rubin MA, Sander C, Stein LD, Stuart JM, Tsunoda T, Wheeler DA, Johnson R, Reimand J, Gerstein M, Khurana E, Campbell PJ, López-Bigas N; PCAWG 
Drivers and Functional Interpretation Working Group; PCAWG Structural Variation Working Group, Weischenfeldt J, Beroukhim R, Martincorena I, Pedersen JS, Getz G; PCAWG Consortium. Analyses of non-coding somatic drivers in 2,658 cancer whole genomes. Nature 2020; 578(7793): 102-111

96. Calabrese C, Davidson NR, Demircioğlu D, Fonseca NA, He Y, Kahles A, Lehmann KV, Liu F, Shiraishi Y, Soulette CM, Urban L, Greger L, Li S, Liu D, Perry MD, Xiang Q, Zhang F, Zhang J, Bailey P, Erkek S, Hoadley KA, Hou Y, Huska MR, Kilpinen H, Korbel JO, Marin MG, Markowski J, Nandi T, Pan-Hammarström Q, Pedamallu CS, Siebert R, Stark SG, Su H, Tan P, Waszak SM, Yung C, Zhu S, Awadalla P, Creighton CJ, Meyerson M, Ouellette BFF, Wu K, Yang H; PCAWG Transcriptome Working Group, Brazma A, Brooks AN, Göke J, Rätsch G, Schwarz RF, Stegle O, Zhang Z; PCAWG Consortium. Genomic basis for RNA alterations in cancer. Nature 2020; 578(7793): 129-136

97. Miguel-Escalada I, Bonàs-Guarch S, Cebola I, Ponsa-Cobas J, Mendieta-Esteban J, Atla G, Javierre BM, Rolando DMY, Farabella I, Morgan CC, García-Hurtado J, Beucher A, Morán I, Pasquali L, Ramos-Rodríguez M, Appel EVR, Linneberg A, Gjesing AP, Witte DR, Pedersen O, Grarup N, Ravassard P, Torrents D, Mercader JM, Piemonti L, Berney T, de Koning EJP, Kerr-Conte J, Pattou F, Fedko IO, Groop L, Prokopenko I, Hansen T, Marti-Renom MA, Fraser P, Ferrer J. Human pancreatic islet three-dimensional chromatin architecture provides insights into the genetics of type 2 diabetes. Nat Genet 2019; 51(7): 1137-1148

98. Li Y, Roberts ND, Wala JA, Shapira O, Schumacher SE, Kumar K, Khurana E, Waszak S, Korbel JO, Haber JE, Imielinski M; PCAWG Structural Variation Working Group, Weischenfeldt J, Beroukhim R, Campbell PJ; PCAWG Consortium. Patterns of somatic structural variation in human cancer genomes. Nature 2020; 578(7793): 112-121

99. Gerstung M, Jolly C, Leshchiner I, Dentro SC, Gonzalez S, Rosebrock D, Mitchell TJ, Rubanova Y, Anur P, Yu K, Tarabichi M, Deshwar A, Wintersinger J, Kleinheinz K, Vázquez-García I, Haase K, Jerman L, Sengupta S, Macintyre G, Malikic S, Donmez N, Livitz DG, Cmero M, Demeulemeester J, Schumacher S, Fan Y, Yao X, Lee J, Schlesner M, Boutros PC, Bowtell DD, Zhu H, Getz G, Imielinski M, Beroukhim R, Sahinalp SC, Ji Y, Peifer M, Markowetz F, Mustonen V, Yuan K, Wang W, Morris QD; PCAWG Evolution \& Heterogeneity Working Group, Spellman PT, Wedge DC, Van Loo P; PCAWG Consortium. The evolutionary history of 2,658 cancers. Nature 2020; 578(7793): 122-128

100. Yang M, Vesterlund M, Siavelis I, Moura-Castro LH, Castor A, Fioretos T, Jafari R, Lilljebjörn H, Odom DT, Olsson L, Ravi N, Woodward EL, Harewood L, Lehtiö J, Paulsson K. Proteogenomics and Hi-C reveal transcriptional dysregulation in high hyperdiploid childhood acute lymphoblastic leukemia. Nat Commun 2019; 10(1): 1519

101. Zhang Z, Pan Z, Ying Y, Xie Z, Adhikari S, Phillips J, Carstens RP, Black DL, Wu Y, Xing Y. Deep-learning augmented RNA-seq analysis of transcript splicing. Nat Methods 2019; 16(4): 307-310

102. van Galen P, Hovestadt V, Wadsworth Ii MH, Hughes TK, Griffin GK, Battaglia S, Verga JA, Stephansky J, Pastika TJ, Lombardi Story J, Pinkus GS, Pozdnyakova O, Galinsky I, Stone RM, Graubert TA, Shalek AK, Aster JC, Lane AA, Bernstein BE. Single-cell RNA-Seq reveals AML hierarchies relevant to disease progression and immunity. Cell 2019; 176(6): 1265-1281.e24

103. Liu Y, Li C, Shen S, Chen X, Szlachta K, Edmonson MN, Shao Y, Ma X, Hyle J, Wright S, Ju B, Rusch MC, Liu Y, Li B, Macias M, Tian L, Easton J, Qian M, Yang JJ, Hu S, Look AT, Zhang J. Discovery of regulatory noncoding variants in individual cancer genomes by using cis-X. Nat Genet 2020; 52(8): 811-818

104. Witkowski MT, Dolgalev I, Evensen NA, Ma C, Chambers T, Roberts KG, Sreeram S, Dai Y, Tikhonova AN, Lasry A, Qu C, Pei D, Cheng C, Robbins GA, Pierro J, Selvaraj S, Mezzano V, Daves M, Lupo PJ, Scheurer ME, Loomis CA, Mullighan CG, Chen W, Rabin KR, Tsirigos A, Carroll WL, Aifantis I. Extensive remodeling of the immune microenvironment in $\mathrm{B}$ cell acute lymphoblastic leukemia. Cancer Cell 2020; 37(6): 867-882.e12

105. Rodríguez-Hernández G, Opitz FV, Delgado P, Walter C, ÁlvarezPrado AF, González-Herrero I, Auer F, Fischer U, Janssen S, Bartenhagen C, Raboso-Gallego J, Casado-García A, Orfao A, Blanco O, Alonso-López D, Rivas JL, Tena-Dávila SG, Müschen M, Dugas M, Criado FJG, Cenador MBG, Vicente-Dueñas C, Hauer J, Ramiro AR, Sanchez-Garcia I, Borkhardt A. Infectious stimuli promote malignant B-cell acute lymphoblastic leukemia in the absence of AID. Nat Commun 2019; 10(1): 5563

106. Dang J, Wei L, de Ridder J, Su X, Rust AG, Roberts KG, PayneTurner D, Cheng J, Ma J, Qu C, Wu G, Song G, Huether RG, Schulman B, Janke L, Zhang J, Downing JR, van der Weyden L, Adams DJ, Mullighan CG. PAX5 is a tumor suppressor in mouse mutagenesis models of acute lymphoblastic leukemia. Blood 2015; 125(23): 3609-3617

107. Potter N, Jones L, Blair H, Strehl S, Harrison CJ, Greaves M, Kearney L, Russell LJ. Single-cell analysis identifies CRLF2 rearrangements as both early and late events in Down syndrome and non-Down syndrome acute lymphoblastic leukaemia. Leukemia 2019; 33(4): 893-904

108. Mullighan CG, Goorha S, Radtke I, Miller CB, Coustan-Smith E, Dalton JD, Girtman K, Mathew S, Ma J, Pounds SB, Su X, Pui CH, Relling MV, Evans WE, Shurtleff SA, Downing JR. Genome-wide analysis of genetic alterations in acute lymphoblastic leukaemia. Nature 2007; 446(7137): 758-764

109. Churchman ML, Qian M, Te Kronnie G, Zhang R, Yang W, Zhang H, Lana T, Tedrick P, Baskin R, Verbist K, Peters JL, Devidas M, Larsen E, Moore IM, Gu Z, Qu C, Yoshihara H, Porter SN, PruettMiller SM, Wu G, Raetz E, Martin PL, Bowman WP, Winick N, Mardis E, Fulton R, Stanulla M, Evans WE, Relling MV, Pui CH, Hunger SP, Loh ML, Handgretinger R, Nichols KE, Yang JJ, Mullighan CG. Germline genetic IKZF1 variation and predisposition to childhood acute lymphoblastic leukemia. Cancer Cell 2018; 33(5): 937-948.e8

110. Schram AM, Chang MT, Jonsson P, Drilon A. Fusions in solid tumours: diagnostic strategies, targeted therapy, and acquired resistance. Nat Rev Clin Oncol 2017; 14(12): 735-748

111. Le Loarer F, Watson S, Pierron G, de Montpreville VT, Ballet S, Firmin N, Auguste A, Pissaloux D, Boyault S, Paindavoine S, Dechelotte PJ, Besse B, Vignaud JM, Brevet M, Fadel E, Richer W, Treilleux I, Masliah-Planchon J, Devouassoux-Shisheboran M, Zalcman G, Allory Y, Bourdeaut F, Thivolet-Bejui F, RanchereVince D, Girard N, Lantuejoul S, Galateau-Sallé F, Coindre JM, Leary A, Delattre O, Blay JY, Tirode F. SMARCA4 inactivation defines a group of undifferentiated thoracic malignancies transcriptionally related to BAF-deficient sarcomas. Nat Genet 
2015; 47(10): 1200-1205

112. French C. NUT midline carcinoma. Nat Rev Cancer 2014; 14(3): 149-150

113. Alekseyenko AA, Walsh EM, Wang X, Grayson AR, Hsi PT, Kharchenko PV, Kuroda MI, French CA. The oncogenic BRD4NUT chromatin regulator drives aberrant transcription within large topological domains. Genes Dev 2015; 29(14): 1507-1523

114. Hormann FM, Hoogkamer AQ, Beverloo HB, Boeree A, Dingjan I, Wattel MM, Stam RW, Escherich G, Pieters R, den Boer ML, Boer JM. NUTM1 is a recurrent fusion gene partner in B-cell precursor acute lymphoblastic leukemia associated with increased expression of genes on chromosome band 10p12.31-12.2. Haematologica 2019; 104(10): e455-e459

115. Pincez T, Landry JR, Roussy M, Jouan L, Bilodeau M, Laramée L, Couture F, Sinnett D, Gendron P, Hébert J, Oligny L, Rouette A, Tran TH, Wilhelm BT, Bittencourt H, Cellot S. Cryptic recurrent ACIN1-NUTM1 fusions in non-KMT2A-rearranged infant acute lymphoblastic leukemia. Genes Chromosomes Cancer 2020; 59 (2): 125-130

116. Godfrey L, Kerry J, Thorne R, Repapi E, Davies JO, Tapia M, Ballabio E, Hughes JR, Geng H, Konopleva M, Milne TA. MLLAF4 binds directly to a BCL-2 specific enhancer and modulates H3K27 acetylation. Exp Hematol 2017; 47: 64-75

117. de Bock CE, Demeyer S, Degryse S, Verbeke D, Sweron B, Gielen O, Vandepoel R, Vicente C, Vanden Bempt M, Dagklis A, Geerdens E, Bornschein S, Gijsbers R, Soulier J, Meijerink JP, Heinäniemi M, Teppo S, Bouvy-Liivrand M, Lohi O, Radaelli E, Cools J. HOXA9 cooperates with activated JAK/STAT signaling to drive leukemia development. Cancer Discov 2018; 8(5): 616-631

118. Limpens J, Stad R, Vos C, de Vlaam C, de Jong D, van Ommen GJ, Schuuring E, Kluin PM. Lymphoma-associated translocation $\mathrm{t}(14 ; 18)$ in blood B cells of normal individuals. Blood 1995; 85 (9): 2528-2536

119. Dölken G, Illerhaus G, Hirt C, Mertelsmann R. BCL-2/JH rearrangements in circulating $\mathrm{B}$ cells of healthy blood donors and patients with nonmalignant diseases. J Clin Oncol 1996; 14(4): 1333-1344

120. Schüler F, Dölken L, Hirt C, Kiefer T, Berg T, Fusch G, Weitmann K, Hoffmann W, Fusch C, Janz S, Rabkin CS, Dölken G. Prevalence and frequency of circulating t(14;18)-MBR translocation carrying cells in healthy individuals. Int J Cancer 2009; 124 (4): 958-963

121. Roulland S, Kelly RS, Morgado E, Sungalee S, Solal-Celigny P, Colombat P, Jouve N, Palli D, Pala V, Tumino R, Panico S, Sacerdote C, Quirós JR, Gonzáles CA, Sánchez MJ, Dorronsoro M, Navarro C, Barricarte A, Tjønneland A, Olsen A, Overvad K, Canzian F, Kaaks R, Boeing H, Drogan D, Nieters A, ClavelChapelon F, Trichopoulou A, Trichopoulos D, Lagiou P, Buenode-Mesquita HB, Peeters PH, Vermeulen R, Hallmans G, Melin B, Borgquist S, Carlson J, Lund E, Weiderpass E, Khaw KT, Wareham N, Key TJ, Travis RC, Ferrari P, Romieu I, Riboli E, Salles G, Vineis P, Nadel B. $t(14 ; 18)$ Translocation: a predictive blood biomarker for follicular lymphoma. J Clin Oncol 2014; 32 (13): 1347-1355

122. Johnson NA, Savage KJ, Ludkovski O, Ben-Neriah S, Woods R, Steidl C, Dyer MJ, Siebert R, Kuruvilla J, Klasa R, Connors JM, Gascoyne RD, Horsman DE. Lymphomas with concurrent BCL2 and MYC translocations: the critical factors associated with survival. Blood 2009; 114(11): 2273-2279

123. Puente XS, Beà S, Valdés-Mas R, Villamor N, Gutiérrez-Abril J, Martín-Subero JI, Munar M, Rubio-Pérez C, Jares P, Aymerich M, Baumann T, Beekman R, Belver L, Carrio A, Castellano G, Clot G, Colado E, Colomer D, Costa D, Delgado J, Enjuanes A, Estivill X, Ferrando AA, Gelpí JL, González B, González S, González M, Gut M, Hernández-Rivas JM, López-Guerra M, Martín-García D, Navarro A, Nicolás P, Orozco M, Payer AR, Pinyol M, Pisano DG, Puente DA, Queirós AC, Quesada V, Romeo-Casabona CM, Royo C, Royo R, Rozman M, Russiñol N, Salaverría I, Stamatopoulos K, Stunnenberg HG, Tamborero D, Terol MJ, Valencia A, LópezBigas N, Torrents D, Gut I, López-Guillermo A, López-Otín C, Campo E. Non-coding recurrent mutations in chronic lymphocytic leukaemia. Nature 2015; 526(7574): 519-524

124. Put N, Meeus P, Chatelain B, Rack K, Boeckx N, Nollet F, Graux C, Van Den Neste E, Janssens A, Madoe V, Van Hoof A, BilhouNabera C, Wlodarska I, Vandenberghe P, Michaux L. Translocation $\mathrm{t}(14 ; 18)$ is not associated with inferior outcome in chronic lymphocytic leukemia. Leukemia 2009; 23(6): 1201-1204

125. Niitsu N, Okamoto M, Miura I, Hirano M. Clinical features and prognosis of de novo diffuse large B-cell lymphoma with $\mathrm{t}(14 ; 18)$ and 8q24/c-MYC translocations. Leukemia 2009; 23(4): 777-783

126. Leich E, Salaverria I, Bea S, Zettl A, Wright G, Moreno V, Gascoyne RD, Chan WC, Braziel RM, Rimsza LM, Weisenburger DD, Delabie J, Jaffe ES, Lister A, Fitzgibbon J, Staudt LM, Hartmann EM, Mueller-Hermelink HK, Campo E, Ott G, Rosenwald A. Follicular lymphomas with and without translocation $\mathrm{t}(14 ; 18)$ differ in gene expression profiles and genetic alterations. Blood 2009; 114(4): 826-834

127. Le Gouill S, Talmant P, Touzeau C, Moreau A, Garand R, JugeMorineau N, Gaillard F, Gastinne T, Milpied N, Moreau P, Harousseau JL, Avet-Loiseau H. The clinical presentation and prognosis of diffuse large B-cell lymphoma with $\mathrm{t}(14 ; 18)$ and 8q24/c-MYC rearrangement. Haematologica 2007; 92(10): 13351342

128. Guo Y, Karube K, Kawano R, Yamaguchi T, Suzumiya J, Huang GS, Ohshima K. Low-grade follicular lymphoma with $t(14 ; 18)$ presents a homogeneous disease entity otherwise the rest comprises minor groups of heterogeneous disease entities with Bcl2 amplification, Bcl6 translocation or other gene aberrances. Leukemia 2005; 19(6): 1058-1063

129. Godon A, Moreau A, Talmant P, Baranger-Papot L, Geneviève F, Milpied N, Zandecki M, Avet-Loiseau H. Is t(14;18)(q32;q21) a constant finding in follicular lymphoma? An interphase FISH study on 63 patients. Leukemia 2003; 17(1): 255-259

130. Huang JZ, Sanger WG, Greiner TC, Staudt LM, Weisenburger DD, Pickering DL, Lynch JC, Armitage JO, Warnke RA, Alizadeh AA, Lossos IS, Levy R, Chan WC. The $\mathrm{t}(14 ; 18)$ defines a unique subset of diffuse large B-cell lymphoma with a germinal center B-cell gene expression profile. Blood 2002; 99(7): 2285-2290

131. Ye BH, Lista F, Lo Coco F, Knowles DM, Offit K, Chaganti RS, Dalla-Favera R. Alterations of a zinc finger-encoding gene, BCL-6, in diffuse large-cell lymphoma. Science 1993; 262(5134): 747-750

132. Baron BW, Nucifora G, McCabe N, Espinosa R 3rd, Le Beau MM, McKeithan TW. Identification of the gene associated with the recurring chromosomal translocations $\mathrm{t}(3 ; 14)(\mathrm{q} 27 ; \mathrm{q} 32)$ and $\mathrm{t}(3 ; 22)$ (q27;q11) in B-cell lymphomas. Proc Natl Acad Sci USA 1993; 90 (11): 5262-5266 
133. Zhao X, Ren Y, Lawlor M, Shah BD, Park PMC, Lwin T, Wang X, Liu K, Wang M, Gao J, Li T, Xu M, Silva AS, Lee K, Zhang T, Koomen JM, Jiang H, Sudalagunta PR, Meads MB, Cheng F, Bi C, Fu K, Fan H, Dalton WS, Moscinski LC, Shain KH, Sotomayor EM, Wang GG, Gray NS, Cleveland JL, Qi J, Tao J. BCL2 amplicon loss and transcriptional remodeling drives ABT-199 resistance in B cell lymphoma models. Cancer Cell 2019; 35(5): 752-766.e9

134. Wu LM, Wang J, Conidi A, Zhao C, Wang H, Ford Z, Zhang L, Zweier C, Ayee BG, Maurel P, Zwijsen A, Chan JR, Jankowski MP, Huylebroeck D, Lu QR. Zeb2 recruits HDAC-NuRD to inhibit Notch and controls Schwann cell differentiation and remyelination. Nat Neurosci 2016; 19(8): 1060-1072

135. Studd JB, Yang M, Li Z, Vijayakrishnan J, Lu Y, Yeoh AE, Paulsson K, Houlston RS. Genetic predisposition to B-cell acute lymphoblastic leukemia at $14 \mathrm{q} 11.2$ is mediated by a CEBPE promoter polymorphism. Leukemia 2019; 33(1): 1-14

136. Li Z, Abraham BJ, Berezovskaya A, Farah N, Liu Y, Leon T, Fielding A, Tan SH, Sanda T, Weintraub AS, Li B, Shen S, Zhang J, Mansour MR, Young RA, Look AT. APOBEC signature mutation generates an oncogenic enhancer that drives LMO1 expression in T-ALL. Leukemia 2017; 31(10): 2057-2064

137. Moya IM, Umans L, Maas E, Pereira PN, Beets K, Francis A, Sents W, Robertson EJ, Mummery CL, Huylebroeck D, Zwijsen A. Stalk cell phenotype depends on integration of Notch and Smad1/5 signaling cascades. Dev Cell 2012; 22(3): 501-514

138. Fuentealba LC, Eivers E, Ikeda A, Hurtado C, Kuroda H, Pera EM, De Robertis EM. Integrating patterning signals: Wnt/GSK3 regulates the duration of the BMP/Smad1 signal. Cell 2007; 131 (5): 980-993

139. Bi Y, Ehirchiou D, Kilts TM, Inkson CA, Embree MC, Sonoyama W, Li L, Leet AI, Seo BM, Zhang L, Shi S, Young MF. Identification of tendon stem/progenitor cells and the role of the extracellular matrix in their niche. Nat Med 2007; 13(10): 12191227

140. Shi Y, Massagué J. Mechanisms of TGF- $\beta$ signaling from cell membrane to the nucleus. Cell 2003; 113(6): 685-700

141. Zaliova M, Potuckova E, Lukes J Jr, Winkowska L, Starkova J, Janotova I, Sramkova L, Stary J, Zuna J, Stanulla M, Zimmermann M, Bornhauser B, Bourquin JP, Eckert C, Cario G, Trka J. Frequency and prognostic impact of ZEB2 H1038 and 1072 mutations in childhood B-other acute lymphoblastic leukemia. Haematologica 2020; [Epub ahead of print] doi: 10.3324/ haematol.2020.249094

142. Katerndahl CDS, Heltemes-Harris LM, Willette MJL, Henzler CM, Frietze S, Yang R, Schjerven H, Silverstein KAT, Ramsey LB, Hubbard G, Wells AD, Kuiper RP, Scheijen B, van Leeuwen FN, Müschen M, Kornblau SM, Farrar MA. Antagonism of B cell enhancer networks by STAT5 drives leukemia and poor patient survival. Nat Immunol 2017; 18(6): 694-704

143. Shao DD, Xue W, Krall EB, Bhutkar A, Piccioni F, Wang X, Schinzel AC, Sood S, Rosenbluh J, Kim JW, Zwang Y, Roberts TM, Root DE, Jacks T, Hahn WC. KRAS and YAP1 converge to regulate EMT and tumor survival. Cell 2014; 158(1): 171-184

144. Lauberth SM, Rauchman M. A conserved 12-amino acid motif in Sall1 recruits the nucleosome remodeling and deacetylase corepressor complex. J Biol Chem 2006; 281(33): 23922-23931
145. Miller NL, Lawson C, Kleinschmidt EG, Tancioni I, Uryu S, Schlaepfer DD. A non-canonical role for Rgnef in promoting integrin-stimulated focal adhesion kinase activation. J Cell Sci 2013; 126(21): 5074-5085

146. Graczyk-Jarzynka A, Zagozdzon R, Muchowicz A, Siernicka M, Juszczynski P, Firczuk M. New insights into redox homeostasis as a therapeutic target in B-cell malignancies. Curr Opin Hematol 2017; 24(4): 393-401

147. Mason CC, Khorashad JS, Tantravahi SK, Kelley TW, Zabriskie MS, Yan D, Pomicter AD, Reynolds KR, Eiring AM, Kronenberg Z, Sherman RL, Tyner JW, Dalley BK, Dao KH, Yandell M, Druker BJ, Gotlib J, O'Hare T, Deininger MW. Age-related mutations and chronic myelomonocytic leukemia. Leukemia 2016; 30(4): 906-913

148. Boutboul D, Kuehn HS, Van de Wyngaert Z, Niemela JE, Callebaut I, Stoddard J, Lenoir C, Barlogis V, Farnarier C, Vely F, Yoshida N, Kojima S, Kanegane H, Hoshino A, Hauck F, Lhermitte L, Asnafi V, Roehrs P, Chen S, Verbsky JW, Calvo KR, Husami A, Zhang K, Roberts J, Amrol D, Sleaseman J, Hsu AP, Holland SM, Marsh R, Fischer A, Fleisher TA, Picard C, Latour S, Rosenzweig SD. Dominant-negative IKZF1 mutations cause a $\mathrm{T}$, $\mathrm{B}$, and myeloid cell combined immunodeficiency. J Clin Invest 2018; 128(7): 3071-3087

149. Rusch M, Nakitandwe J, Shurtleff S, Newman S, Zhang Z, Edmonson MN, Parker M, Jiao Y, Ma X, Liu Y, Gu J, Walsh MF, Becksfort J, Thrasher A, Li Y, McMurry J, Hedlund E, Patel A, Easton J, Yergeau D, Vadodaria B, Tatevossian RG, Raimondi S, Hedges D, Chen X, Hagiwara K, McGee R, Robinson GW, Klco JM, Gruber TA, Ellison DW, Downing JR, Zhang J. Clinical cancer genomic profiling by three-platform sequencing of whole genome, whole exome and transcriptome. Nat Commun 2018; 9 (1): 3962

150. Li Z, Jiang N, Lim EH, Chin WHN, Lu Y, Chiew KH, Kham SKY, Yang W, Quah TC, Lin HP, Tan AM, Ariffin H, Yang JJ, Yeoh AE. Identifying IGH disease clones for MRD monitoring in childhood B-cell acute lymphoblastic leukemia using RNA-Seq. Leukemia 2020; 34(9): 2418-2429

151. Hagiwara K, Ding L, Edmonson MN, Rice SV, Newman S, Easton J, Dai J, Meshinchi S, Ries RE, Rusch M, Zhang J. RNAIndel: discovering somatic coding indels from tumor RNA-Seq data. Bioinformatics 2020; 36(5): 1382-1390

152. Tian L, Li Y, Edmonson MN, Zhou X, Newman S, McLeod C, Thrasher A, Liu Y, Tang B, Rusch MC, Easton J, Ma J, Davis E, Trull A, Michael JR, Szlachta K, Mullighan C, Baker SJ, Downing JR, Ellison DW, Zhang J. CICERO: a versatile method for detecting complex and diverse driver fusions using cancer RNA sequencing data. Genome Biol 2020; 21(1): 126

153. Brown LM, Lonsdale A, Zhu A, Davidson NM, Schmidt B, Hawkins A, Wallach E, Martin M, Mechinaud FM, Khaw SL, Bartolo RC, Ludlow LEA, Challis J, Brooks I, Petrovic V, Venn NC, Sutton R, Majewski IJ, Oshlack A, Ekert PG. The application of RNA sequencing for the diagnosis and genomic classification of pediatric acute lymphoblastic leukemia. Blood Adv 2020; 4(5): 930-942

154. Yizhak K, Aguet F, Kim J, Hess JM, Kübler K, Grimsby J, Frazer R, Zhang H, Haradhvala NJ, Rosebrock D, Livitz D, Li X, ArichLandkof E, Shoresh N, Stewart C, Segrè AV, Branton PA, Polak P, 
Ardlie KG, Getz G. RNA sequence analysis reveals macroscopic somatic clonal expansion across normal tissues. Science 2019; 364 (6444): eaaw0726

155. Arindrarto W, Borràs DM, de Groen RAL, van den Berg RR, Locher IJ, van Diessen SAME, van der Holst R, van der Meijden ED, Honders MW, de Leeuw RH, Verlaat W, Jedema I, Kroes WGM, Knijnenburg J, van Wezel T, Vermaat JSP, Valk PJM, Janssen B, de Knijff P, van Bergen CAM, van den Akker EB, Hoen PAC, Kiełbasa SM, Laros JFJ, Griffioen M, Veelken H. Comprehensive diagnostics of acute myeloid leukemia by whole transcriptome RNA sequencing. Leukemia 2020; [Epub ahead of print] doi: 10.1038/s41375-020-0762-8

156. Gu M, Zwiebel M, Ong SH, Boughton N, Nomdedeu J, Basheer F, Nannya Y, Quiros PM, Ogawa S, Cazzola M, Rad R, Butler AP, Vijayabaskar MS, Vassiliou GS. RNAmut: robust identification of somatic mutations in acute myeloid leukemia using RNAsequencing. Haematologica 2020; 105(6): e290-e293

157. Audemard EO, Gendron P, Feghaly A, Lavallée VP, Hébert J, Sauvageau G, Lemieux S. Targeted variant detection using unaligned RNA-Seq reads. Life Sci Alliance 2019; 2(4): e201900336

158. Kosugi S, Momozawa Y, Liu X, Terao C, Kubo M, Kamatani Y. Comprehensive evaluation of structural variation detection algorithms for whole genome sequencing. Genome Biol 2019; 20(1): 117

159. Wang C, Gong B, Bushel PR, Thierry-Mieg J, Thierry-Mieg D, Xu J, Fang H, Hong H, Shen J, Su Z, Meehan J, Li X, Yang L, Li H, Łabaj PP, Kreil DP, Megherbi D, Gaj S, Caiment F, van Delft J, Kleinjans J, Scherer A, Devanarayan V, Wang J, Yang Y, Qian HR, Lancashire LJ, Bessarabova M, Nikolsky Y, Furlanello C, Chierici M, Albanese D, Jurman G, Riccadonna S, Filosi M, Visintainer R, Zhang KK, Li J, Hsieh JH, Svoboda DL, Fuscoe JC, Deng Y, Shi L, Paules RS, Auerbach SS, Tong W. The concordance between RNA-seq and microarray datadepends on chemical treatment and transcript abundance. Nat Biotechnol 2014; 32(9): 926-932

160. Li B, Brady SW, Ma X, Shen S, Zhang Y, Li Y, Szlachta K, Dong L, Liu Y, Yang F, Wang N, Flasch DA, Myers MA, Mulder HL, Ding L, Liu Y, Tian L, Hagiwara K, Xu K, Zhou X, Sioson E, Wang T, Yang L, Zhao J, Zhang H, Shao Y, Sun H, Sun L, Cai J, Sun HY, Lin TN, Du L, Li H, Rusch M, Edmonson MN, Easton J, Zhu X, Zhang J, Cheng C, Raphael BJ, Tang J, Downing JR, Alexandrov LB, Zhou BS, Pui CH, Yang JJ, Zhang J. Therapyinduced mutations drive the genomic landscape of relapsed acute lymphoblastic leukemia. Blood 2020; 135(1): 41-55

161. Xiao X, Liu P, Li D, Xia Z, Wang P, Zhang X, Liu M, Liao L, Jiao B, Ren R. Combination therapy of BCR-ABL-positive B cell acute lymphoblastic leukemia by tyrosine kinase inhibitor dasatinib and c-JUN N-terminal kinase inhibition. J Hematol Oncol 2020; 13(1): 80

162. Menzl I, Zhang T, Berger-Becvar A, Grausenburger R, Heller G, Prchal-Murphy M, Edlinger L, Knab VM, Uras IZ, Grundschober E, Bauer K, Roth M, Skucha A, Liu Y, Hatcher JM, Liang Y, Kwiatkowski NP, Fux D, Hoelbl-Kovacic A, Kubicek S, Melo JV, Valent P, Weichhart T, Grebien F, Zuber J, Gray NS, Sexl V. A kinase-independent role for CDK8 in BCR-ABL1 ${ }^{+}$leukemia. Nat Commun 2019; 10(1): 4741

163. Khaw SL, Suryani S, Evans K, Richmond J, Robbins A, Kurmasheva RT, Billups CA, Erickson SW, Guo Y, Houghton
PJ, Smith MA, Carol H, Roberts AW, Huang DC, Lock RB. Venetoclax responses of pediatric ALL xenografts reveal sensitivity of MLL-rearranged leukemia. Blood 2016; 128(10): 13821395

164. Stein EM, Garcia-Manero G, Rizzieri DA, Tibes R, Berdeja JG, Savona MR, Jongen-Lavrenic M, Altman JK, Thomson B, Blakemore SJ, Daigle SR, Waters NJ, Suttle AB, Clawson A, Pollock R, Krivtsov A, Armstrong SA, DiMartino J, Hedrick E, Löwenberg B, Tallman MS. The DOT1L inhibitor pinometostat reduces $\mathrm{H} 3 \mathrm{~K} 79$ methylation and has modest clinical activity in adult acute leukemia. Blood 2018; 131(24): 2661-2669

165. Stubbs MC, Kim W, Bariteau M, Davis T, Vempati S, Minehart J, Witkin M, Qi J, Krivtsov AV, Bradner JE, Kung AL, Armstrong SA. Selective inhibition of HDAC1 and HDAC2 as a potential therapeutic option for B-ALL. Clin Cancer Res 2015; 21(10): 2348-2358

166. Krivtsov AV, Evans K, Gadrey JY, Eschle BK, Hatton C, Uckelmann HJ, Ross KN, Perner F, Olsen SN, Pritchard T, McDermott L, Jones CD, Jing D, Braytee A, Chacon D, Earley E, McKeever BM, Claremon D, Gifford AJ, Lee HJ, Teicher BA, Pimanda JE, Beck D, Perry JA, Smith MA, McGeehan GM, Lock RB, Armstrong SA. A Menin-MLL inhibitor induces specific chromatin changes and eradicates disease in models of MLLrearranged leukemia. Cancer Cell 2019; 36(6): 660-673.e11

167. Ying Z, Huang XF, Xiang X, Liu Y, Kang X, Song Y, Guo X, Liu H, Ding N, Zhang T, Duan P, Lin Y, Zheng W, Wang X, Lin N, Tu M, Xie Y, Zhang C, Liu W, Deng L, Gao S, Ping L, Wang X, Zhou N, Zhang J, Wang Y, Lin S, Mamuti M, Yu X, Fang L, Wang S, Song H, Wang G, Jones L, Zhu J, Chen SY. A safe and potent antiCD19 CAR T cell therapy. Nat Med 2019; 25(6): 947-953

168. Pan J, Niu Q, Deng B, Liu S, Wu T, Gao Z, Liu Z, Zhang Y, Qu X, Zhang Y, Liu S, Ling Z, Lin Y, Zhao Y, Song Y, Tan X, Zhang Y, Li Z, Yin Z, Chen B, Yu X, Yan J, Zheng Q, Zhou X, Gao J, Chang AH, Feng X, Tong C. CD22 CAR T-cell therapy in refractory or relapsed B acute lymphoblastic leukemia. Leukemia 2019; 33(12): 2854-2866

169. Fry TJ, Shah NN, Orentas RJ, Stetler-Stevenson M, Yuan CM, Ramakrishna S, Wolters P, Martin S, Delbrook C, Yates B, Shalabi H, Fountaine TJ, Shern JF, Majzner RG, Stroncek DF, Sabatino M, Feng Y, Dimitrov DS, Zhang L, Nguyen S, Qin H, Dropulic B, Lee DW, Mackall CL. CD22-targeted CAR T cells induce remission in B-ALL that is naive or resistant to CD19-targeted CAR immunotherapy. Nat Med 2018; 24(1): 20-28

170. Kantarjian H, Stein A, Gökbuget N, Fielding AK, Schuh AC, Ribera JM, Wei A, Dombret H, Foà R, Bassan R, Arslan Ö, Sanz MA, Bergeron J, Demirkan F, Lech-Maranda E, Rambaldi A, Thomas X, Horst HA, Brüggemann M, Klapper W, Wood BL, Fleishman A, Nagorsen D, Holland C, Zimmerman Z, Topp MS. Blinatumomab versus chemotherapy for advanced acute lymphoblastic leukemia. N Engl J Med 2017; 376(9): 836-847

171. Curran KJ, Margossian SP, Kernan NA, Silverman LB, Williams DA, Shukla N, Kobos R, Forlenza CJ, Steinherz P, Prockop S, Boulad F, Spitzer B, Cancio MI, Boelens JJ, Kung AL, Szenes V, Park JH, Sauter CS, Heller G, Wang X, Senechal B, O'Reilly RJ, Riviere I, Sadelain M, Brentjens RJ. Toxicity and response after CD19-specific CAR T-cell therapy in pediatric/young adult relapsed/refractory B-ALL. Blood 2019; 134(26): 2361-2368

172. Mohty M, Gautier J, Malard F, Aljurf M, Bazarbachi A, 
Chabannon C, Kharfan-Dabaja MA, Savani BN, Huang H, Kenderian S, Nagler A, Perales MA. CD19 chimeric antigen receptor-T cells in B-cell leukemia and lymphoma: current status and perspectives. Leukemia 2019; 33(12): 2767-2778

173. Chen H, Wang F, Zhang P, Zhang Y, Chen Y, Fan X, Cao X, Liu J, Yang Y, Wang B, Lei B, Gu L, Bai J, Wei L, Zhang R, Zhuang Q, Zhang W, Zhao W, He A. Management of cytokine release syndrome related to CAR-T cell therapy. Front Med 2019; 13(5): 610-617

174. Chen Z. Prospects of immunotherapy for cancer. Front Med 2019; 13(1): $1-2$

175. Schultz KR, Carroll A, Heerema NA, Bowman WP, Aledo A, Slayton WB, Sather H, Devidas M, Zheng HW, Davies SM, Gaynon PS, Trigg M, Rutledge R, Jorstad D, Winick N, Borowitz MJ, Hunger SP, Carroll WL, Camitta B, Children's Oncology Group. Long-term follow-up of imatinib in pediatric Philadelphia chromosome-positive acute lymphoblastic leukemia: Children's Oncology Group study AALL0031. Leukemia 2014; 28(7): 14671471

176. Malard F, Mohty M. Acute lymphoblastic leukaemia. Lancet 2020; 395(10230): 1146-1162

177. Mikhael J, Richardson P, Usmani SZ, Raje N, Bensinger W, Karanes C, Campana F, Kanagavel D, Dubin F, Liu Q, Semiond D, Anderson K. A phase 1b study of isatuximab plus pomalidomide/ dexamethasone in relapsed/refractory multiple myeloma. Blood 2019; 134(2): 123-133

178. Diaz-Flores E, Comeaux EQ, Kim KL, Melnik E, Beckman K, Davis KL, Wu K, Akutagawa J, Bridges O, Marino R, Wohlfeil M, Braun BS, Mullighan CG, Loh ML. Bcl-2 is a therapeutic target for hypodiploid B-lineage acute lymphoblastic leukemia. Cancer Res 2019; 79(9): 2339-2351

179. Li D, Hu Y, Jin Z, Zhai Y, Tan Y, Sun Y, Zhu S, Zhao C, Chen B, Zhu J, Chen Z, Chen S, Li J, Liu H. TanCAR T cells targeting CD19 and CD133 efficiently eliminate MLL leukemic cells. Leukemia 2018; 32(9): 2012-2016

180. Kim E, Hurtz C, Koehrer S, Wang Z, Balasubramanian S, Chang BY, Müschen M, Davis RE, Burger JA. Ibrutinib inhibits pre$\mathrm{BCR}^{+}$B-cell acute lymphoblastic leukemia progression by targeting BTK and BLK. Blood 2017; 129(9): 1155-1165

181. Tzoneva G, Dieck CL, Oshima K, Ambesi-Impiombato A,
Sánchez-Martín M, Madubata CJ, Khiabanian H, Yu J, Waanders E, Iacobucci I, Sulis ML, Kato M, Koh K, Paganin M, Basso G, Gastier-Foster JM, Loh ML, Kirschner-Schwabe R, Mullighan CG, Rabadan R, Ferrando AA. Clonal evolution mechanisms in NT5C2 mutant-relapsed acute lymphoblastic leukaemia. Nature 2018; 553(7689): 511-514

182. Ohki K, Takahashi H, Fukushima T, Nanmoku T, Kusano S, Mori M, Nakazawa Y, Yuza Y, Migita M, Okuno H, Morimoto A, Yoshino H, Kato M, Hayashi Y, Manabe A, Ohara A, Hasegawa D, Inukai T, Tomizawa D, Koh K, Kiyokawa N, Tokyo Children's Cancer Study Group (TCCSG). Impact of immunophenotypic characteristics on genetic subgrouping in childhood acute lymphoblastic leukemia: Tokyo Children's Cancer Study Group (TCCSG) study L04-16. Genes Chromosomes Cancer 2020; 59 (10): 551-561

183. Greaves M. A causal mechanism for childhood acute lymphoblastic leukaemia. Nat Rev Cancer 2018; 18(8): 471-484

184. Meyer LK, Hermiston ML. The epigenome in pediatric acute lymphoblastic leukemia: drug resistance and therapeutic opportunities. Cancer Drug Resist 2019; 2:313-325

185. Fang DD, Wen $\mathrm{D}, \mathrm{Xu}$ Y. Identification of cancer stem cells provides novel tumor models for drug discovery. Front Med 2012; 6(2): 112-121

186. Good Z, Sarno J, Jager A, Samusik N, Aghaeepour N, Simonds EF, White L, Lacayo NJ, Fantl WJ, Fazio G, Gaipa G, Biondi A, Tibshirani R, Bendall SC, Nolan GP, Davis KL. Single-cell developmental classification of B cell precursor acute lymphoblastic leukemia at diagnosis reveals predictors of relapse. Nat Med 2018; 24(4): 474-483

187. Tan Y, Liu H, Chen S. Mutant DNA methylation regulators endow hematopoietic stem cells with the preleukemic stem cell property, a requisite of leukemia initiation and relapse. Front Med 2015; 9(4): 412-420

188. James AR, Schroeder MP, Neumann M, Bastian L, Eckert C, Gökbuget N, Tanchez JO, Schlee C, Isaakidis K, Schwartz S, Burmeister $\mathrm{T}$, von Stackelberg A, Rieger MA, Göllner S, Horstman M, Schrappe M, Kirschner-Schwabe R, Brüggemann M, Müller-Tidow C, Serve H, Akalin A, Baldus CD. Long noncoding RNAs defining major subtypes of $\mathrm{B}$ cell precursor acute lymphoblastic leukemia. J Hematol Oncol 2019; 12(1): 8 